\title{
Efficacy of homemade botanical insecticides based on traditional knowledge. A review
}

\author{
Julien Dougoud $^{1} \cdot$ Stefan Toepfer ${ }^{1} \cdot$ Melanie Bateman $^{1} \cdot$ Wade H. Jenner ${ }^{1}$
}

Accepted: 17 May 2019 / Published online: 20 June 2019

(C) The Author(s) 2019

\begin{abstract}
Homemade botanical insecticides are widely used by subsistence and transitional farmers in low-income countries. Their use is often driven by the limited availability or cost of commercial pesticides. Homemade botanical insecticides are often recommended by agricultural extension services and some development organizations. However, this could be questioned because scientific evidence of their efficacy and safety may not be available or accessible. Although botanicals with insecticidal properties have been widely studied, a synthesis focusing specifically on homemade preparations used in realistic field or storage conditions is missing. In this paper, we review efficacy assessments of botanicals used to prepare homemade insecticides. This covers twelve botanicals recommended by national extension partners in 20 countries within the global agricultural Plantwise program. These are as follows: garlic (Allium sativum), neem (Azadirachta indica), chili pepper (Capsicum spp.), Siam weed (Chromolaena odorata), mother of cocoa (Gliricidia sepium), chinaberry (Melia azedarach), moringa (Moringa oleifera), tobacco (Nicotiana tabacum), clove basil (Ocimum gratissimum), tephrosia (Tephrosia vogelii), tree marigold (Tithonia diversifolia), and bitter leaf (Vernonia amygdalina). This review shows that (1) all the selected botanicals contain active ingredients with insecticidal, antifeedant, or repellent properties, and (2) homemade insecticides based on all the selected botanicals have been used with some success to control pests or prevent damage, although efficacy was variable and often lower than the positive controls (synthetic pesticides). Factors affecting the efficacy of homemade botanical insecticide include variation in active ingredient content and concentration in plant material, as well as variation in the preparation process. In conclusion, there is some evidence that homemade botanical insecticides could contribute to reducing losses in food production. Since further research is needed to better understand their variable efficacy and potential health and environmental risks, those who promote the use of homemade botanical insecticides should also communicate those "unknowns" to the farmers who use such products.
\end{abstract}

Keywords Pesticide . Pest control · Arthropod · Insect · Mite · Antifeedant · Deterrent · Repellent · Human safety · Environmental safety $\cdot$ Food security

\section{Introduction}

Globally, yield losses due to arthropods, diseases, and weeds are estimated to account for about 35\% in major crops. Losses may exceed $50 \%$ in developing regions where pest control options are limited (Oerke 2006). In some cases, damage by pests, and arthropods in particular, can lead to even higher losses or total crop failure (Abate et al. 2000; Grzywacz et al. 2014; Lingappa et al. 2004). This highlights the key role

Wade H. Jenner

w.jenner@cabi.org

1 CABI, Rue des Grillons 1, CH-2800 Delémont, Switzerland of crop protection in safeguarding yields and thus ensuring food security. Although components of integrated pest management are now widely applied in developed countries, reliance on pesticides to control pest outbreaks remains high (Farrar et al. 2016; Vasileiadis et al. 2017). Synthetic pesticides are intensively used in developed and transitional countries (FAO 2013). In developing countries, many subsistence and transitional farmers do not have access to synthetic pesticides, or cannot afford them (Abate et al. 2000; Nyirenda et al. 2011). Similarly, commercial preparations of alternatives, such as biological control agents or botanical pesticides ("botanicals"), are often not available and may also be expensive (Amoabeng et al. 2014; Dougoud et al. 2018).

Botanicals were used for control of agricultural pests in ancient China, Egypt, Greece, and India already two millennia 
ago (Isman 2006). Still today, traditional pest control using botanicals for the protection of field crops or during storage is widespread and popular among subsistence and transitional farmers (Belmain and Stevenson 2001; Gerken et al. 2001). For example, up to $100 \%$ of the farmers in some regions of Zimbabwe and Uganda report using botanicals or have used them (Makaza and Mabhegedhe 2016; Nyirenda et al. 2011). These typically involve simple preparations, such as ground or whole plant material, and aqueous extracts thereof (Fig. 1).

Globally, over 2500 plant species belonging to 235 families have been reported to have biological activities against pests (Isman 2006; Roy et al. 2016; Saxena 1998; Stevenson et al. 2017). More specifically, the use of a wide variety of botanicals for insect pest control is highlighted in many farmer surveys, such as with 10 botanicals being used by farmers in Northern Malawi, 7 in Zambia (Nyirenda et al. 2011), 34 in the Lake Victoria basin in Uganda (Kamatenesi-Mugisha et al. 2010), or 11 in one district of the Tamil Nadu State in India (Kiruba et al. 2008).

In light of the limited availability and prohibitive cost of synthetic pesticides for subsistence and transitional farmers, some consider botanicals to be a valid alternative to synthetic pesticides (Isman 2008). A number of government agricultural departments actively promote botanical preparations in their advisory materials. As such, national extension partners in Plantwise (www.plantwise.org), a global agricultural development program led by CABI (Centre for Agriculture and Bioscience International), sometimes include homemade pesticide preparations in their recommendations and extension materials. An analysis of 811 pest management decision guides developed by national extension partners in Plantwise (www.plantwise.org/KnowledgeBank/home.aspx) showed that botanical preparations are frequently recommended in these extension materials in African countries (particularly in
Zambia, Tanzania, Sierra Leone, Kenya, Ethiopia, and Mozambique), in Central, South, and Southeast Asian countries (particularly in Afghanistan, India, Myanmar, Nepal, Cambodia, and Sri Lanka), and to a lesser extent in the Americas (particularly in Nicaragua). The most widely recommended botanical was, by far, neem, followed by chili pepper, garlic, and tephrosia; however, 25 other botanicals were also recommended in the extension materials reviewed (J. Dougoud, unpublished).

The appropriateness of the recommendation and use of botanicals for pest control can be questioned. In general, the supporting evidence for the use of botanicals is very old and their efficacy needs to be reevaluated. Some of the botanicals that are being used for pest control may lack active ingredients, which would make their use by smallholder farmers a waste of time. Moreover, results may be unpredictable due to varying active ingredient content and concentration in the used plant material (Sarasan et al. 2011), as well as differences in the preparation method. Finally, their toxicity to nontargets (species that are not the intended target) has often not been evaluated. Although there is gathering evidence that some of the botanicals used for pest control are less toxic to nontargets than synthetic pesticides (Tembo et al. 2018), others may be hazardous to users, livestock, or the environment. Yet, the use of botanicals for pest control is so widespread that it cannot be ignored. Over the last decades, the efficacy of botanicals used in traditional pest management has been widely investigated in research trials. However, a synthesis of the scientific information on homemade botanical insecticides used by subsistence and transitional farmers is missing.

This review was therefore conducted to investigate the scientific basis of homemade insecticides for 12 botanicals with regard to their efficacy and reliability at reducing arthropod pest populations or their impact. Findings show the potential
Fig. 1 Women preparing a homemade insecticide in Odisha State, India. A woman is crushing garlic cloves. A heap of neem leaves can be seen on the bottom left of the picture. Photo credit: Basudev Mahapatra

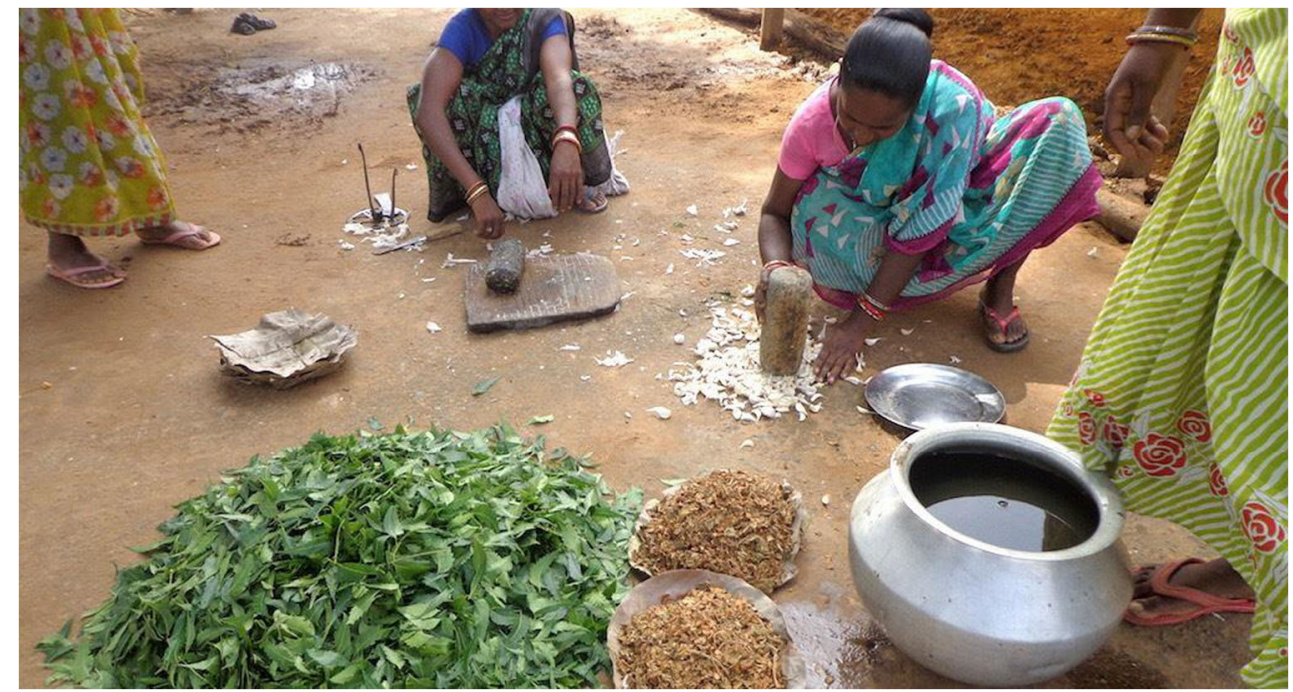


and limitations of the selected homemade botanical insecticides as alternatives to pesticides, with a discussion on factors affecting efficacy. Human and environmental safety, as well as practical and economic aspects, are also briefly discussed.

\section{Methodology}

\subsection{Methodology and scope of information search}

The selection of the botanicals was based on (i) their recommendation in pest management decisions guides developed by agricultural extension and plant protection partners in the Plantwise program and (ii) availability of at least 5 literature references documenting the efficacy of homemade botanical insecticides in conditions similar to farmer practice. The 12 botanicals reviewed are as follows: garlic, Allium sativum L. (Asparagales: Amaryllidaceae); neem, Azadirachta indica Juss. (Sapindales: Meliaceae); chili pepper, Capsicum spp. (Solanales: Solanaceae); Siam weed, Chromolaena odorata (L.) R. M. King \& H. Rob (Asterales: Asteraceae); mother of cocoa, Gliricidia sepium (Jacq.) Kunth ex Walp. (Fabales: Fabaceae); chinaberry, Melia azedarach L. (Sapindales: Meliaceae); moringa, Moringa oleifera Lam. (Capparidales: Moringaceae); tobacco, Nicotiana tabacum L. (Solanales: Solanaceae); clove basil, Ocimum gratissimum L. (Lamiales: Lamiaceae); tephrosia, Tephrosia vogelii Hook f. (Fabales: Fabaceae); tree marigold, Tithonia diversifolia (Hemsley) A. Gray (Asterales: Asteraceae); and bitter leaf, Vernonia amygdalina (Delile) (Asterales: Asteraceae).

This review was based on a literature search using the online repository CAB Direct (https://www.cabdirect.org) and Google Scholar (https://scholar.google.com). The search considered all the studies published over the last 30 years, i.e., from 1987 to 2017. It focused on homemade botanical insecticides used for arthropod control. Mixtures of botanicals were not covered in this review. Homemade botanical insecticides were reviewed for their efficacy in field and postharvest applications. Information on the economic viability of these homemade plant protection products was also collected, where available. Human, animal, and environmental safety is only briefly addressed as this complex topic should be covered in another review.

Only efficacy trials which used botanicals in their raw form or which used simple preparation methods (grinding, pounding, aqueous extraction) were considered for the development of Tables 1 and 2. For field applications, only field trials were considered. For storage applications, laboratory trials under realistic storage conditions were included, such as botanicals added to stored grains or beans, due to the limited availability of on-farm trials. Results obtained using commercial extracts and solvents other than water, as well as results obtained in laboratory trials (for field applications), or results obtained in trials that do not reproduce storage conditions (for storage applications) were used as complementary information for discussion.

Over half of the publications identified during this literature search as documenting trials with homemade botanical insecticides did not follow basic scientific procedures. For instance, the methodology was not sufficiently described, no control treatment was included, no exact figures were provided (e.g., results presented in charts with no numerical value), or no statistical analysis was performed. Publications with any of these critical flaws were not considered for this review.

\subsection{Summarizing efficacy trial results}

Table 1 summarizes efficacy trials performed using homemade botanical insecticides in field and storage applications. Results were grouped by botanical and plant material used and then by host crop. It was not possible to group results by target pest species or type because a substantial number of studies were performed under natural conditions and did not distinguish damage done by different pest species. Whenever a study assessed efficacy using multiple parameters and results were consistent, only one parameter was selected for this review; however, two or more parameters were selected when results were inconsistent. These parameters included the number of seeds produced; yield; pest mortality; pest population reduction; number of eggs laid; damage done to leaves, fruits, or whole plant; number of damaged grains; and grain weight loss during storage. Whenever available, data on yield were included.

Not all plant material dosages and application frequency could be included. When there was no statistical difference in efficacy between plant material dosages, the lowest effective dosage was included; however, when there was a statistical difference between dosages, two dosages were selected to underline a dose-dependent effect. In a few cases, two different dosages were included even though they were not statistically different because efficacy varied by a factor of two or more. This was taken as an indication that dosage deserves further investigation. When a botanical was considered ineffective, only the highest dosage was selected to reduce the likelihood that the lack of effect was due to inadequate dosage.

In order to facilitate the comparison among trials, results were transformed into percentages, which were calculated based on the data given. When relevant, Abbott's formula (Abbott 1925) was used. The efficacy percentages shown in Table 1 for both homemade botanical insecticides and positive controls (i.e., a reference product such as a synthetic pesticide) are always relative to the negative controls (i.e., untreated or sprayed with water and adjuvants). 


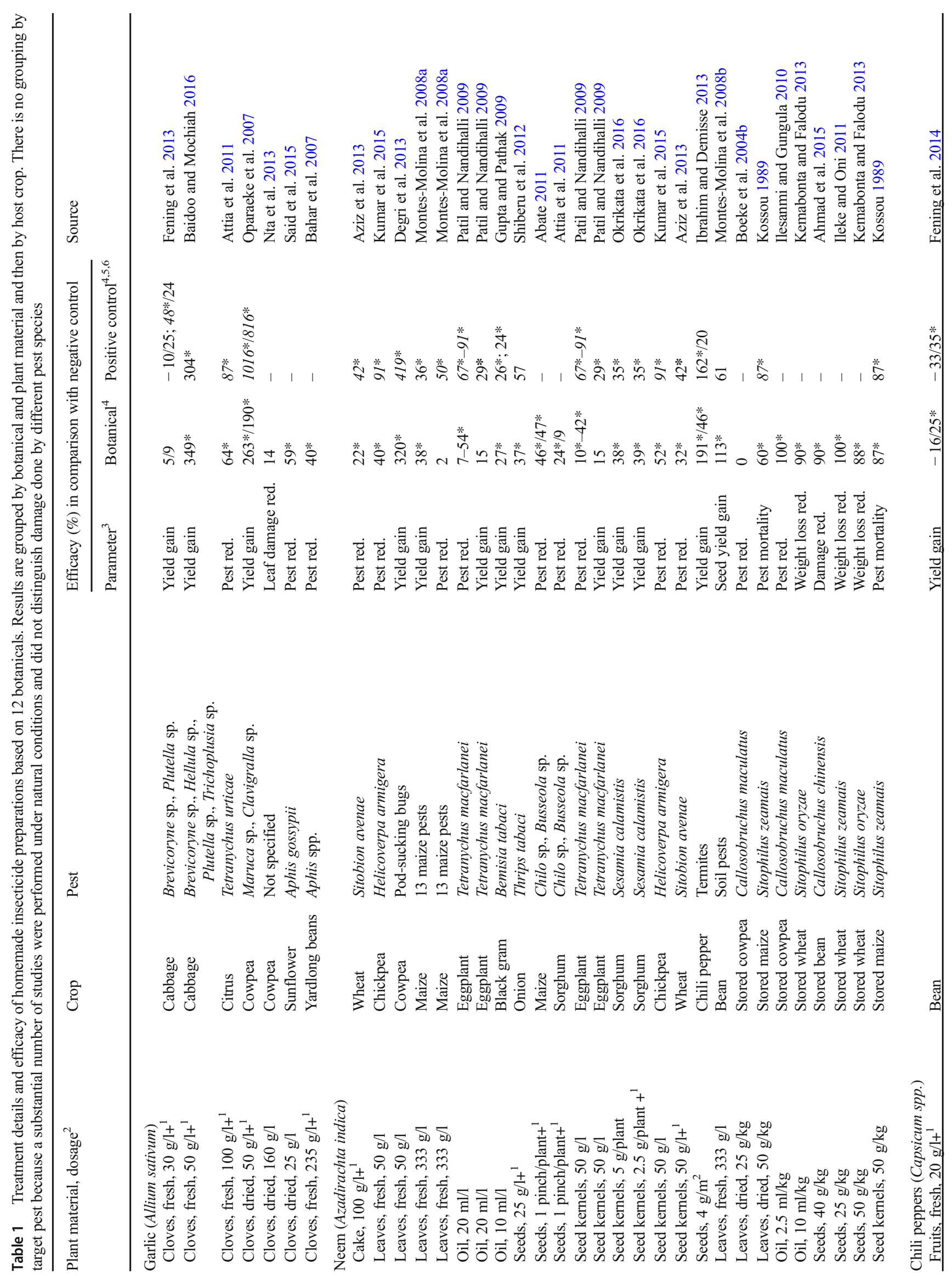




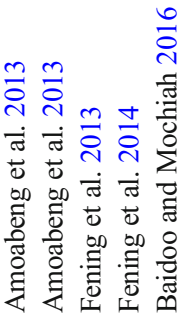

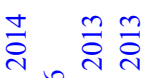
กิ य त त त

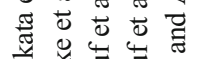

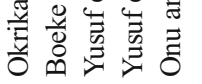

त

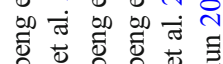

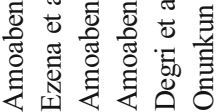

ॠ

तं तं ते तं

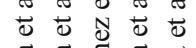

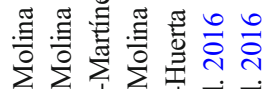

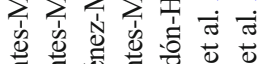

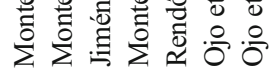

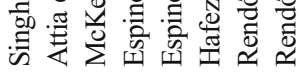

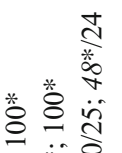

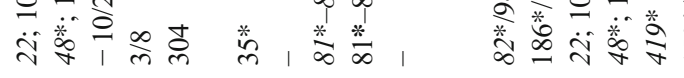

$\stackrel{*}{*} \underset{\infty}{\infty}$

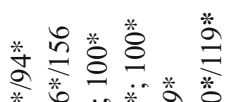

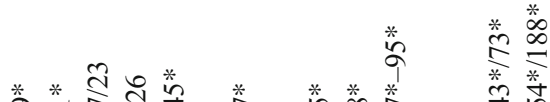

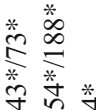

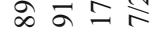

تृ ¿ृं

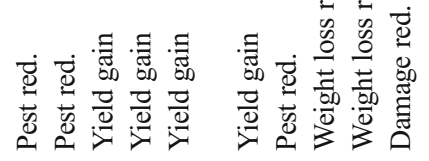

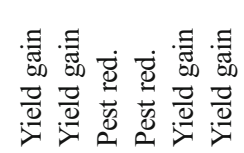

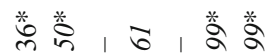

荅葷

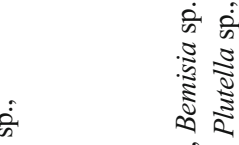

के के की की

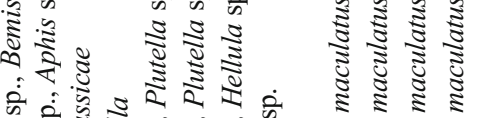

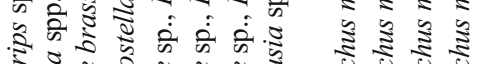

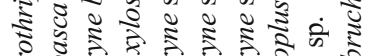

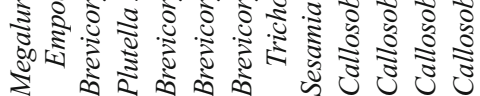

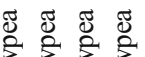

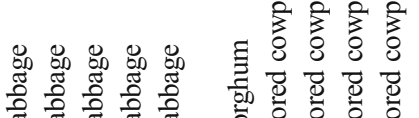

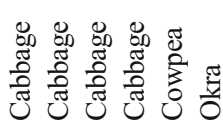

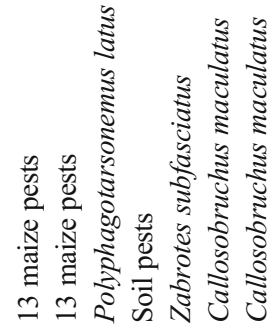

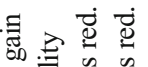

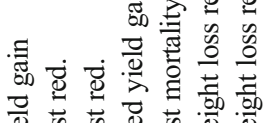

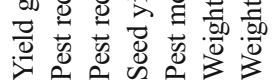

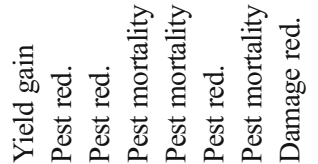
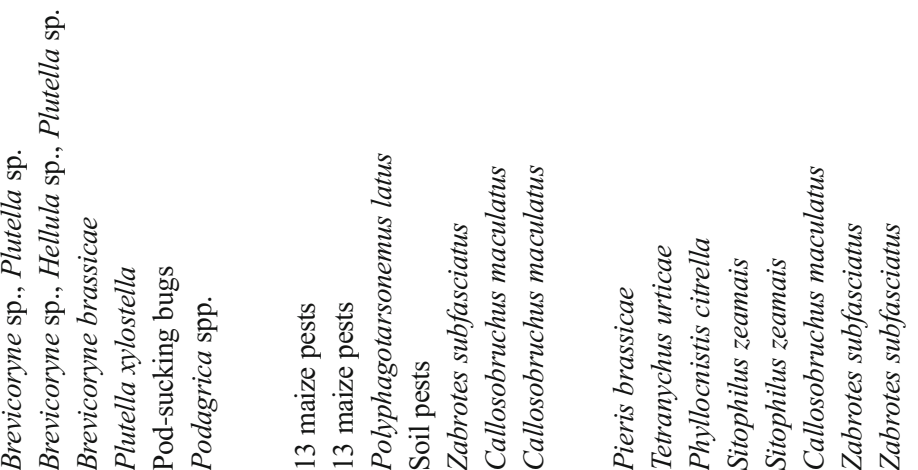

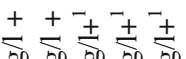

蒙

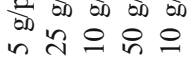
유유 유유유 ती ती ती ती

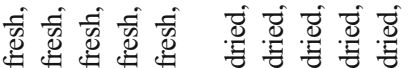

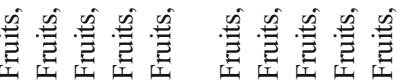
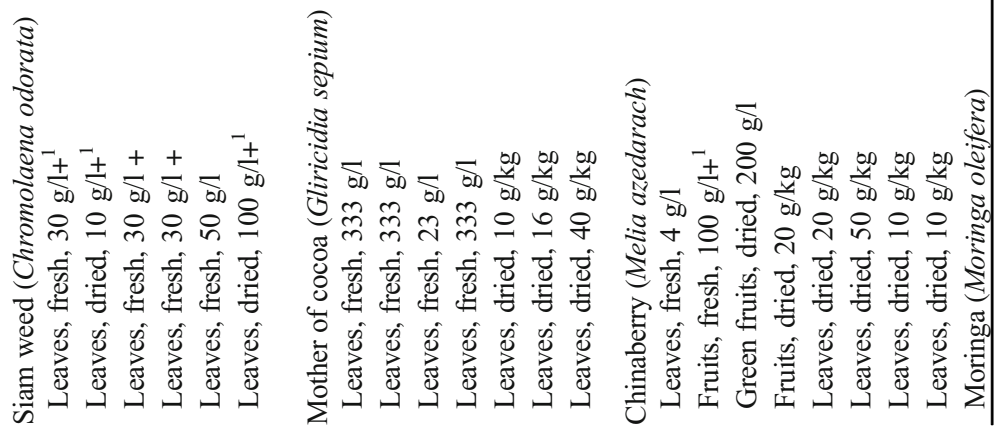


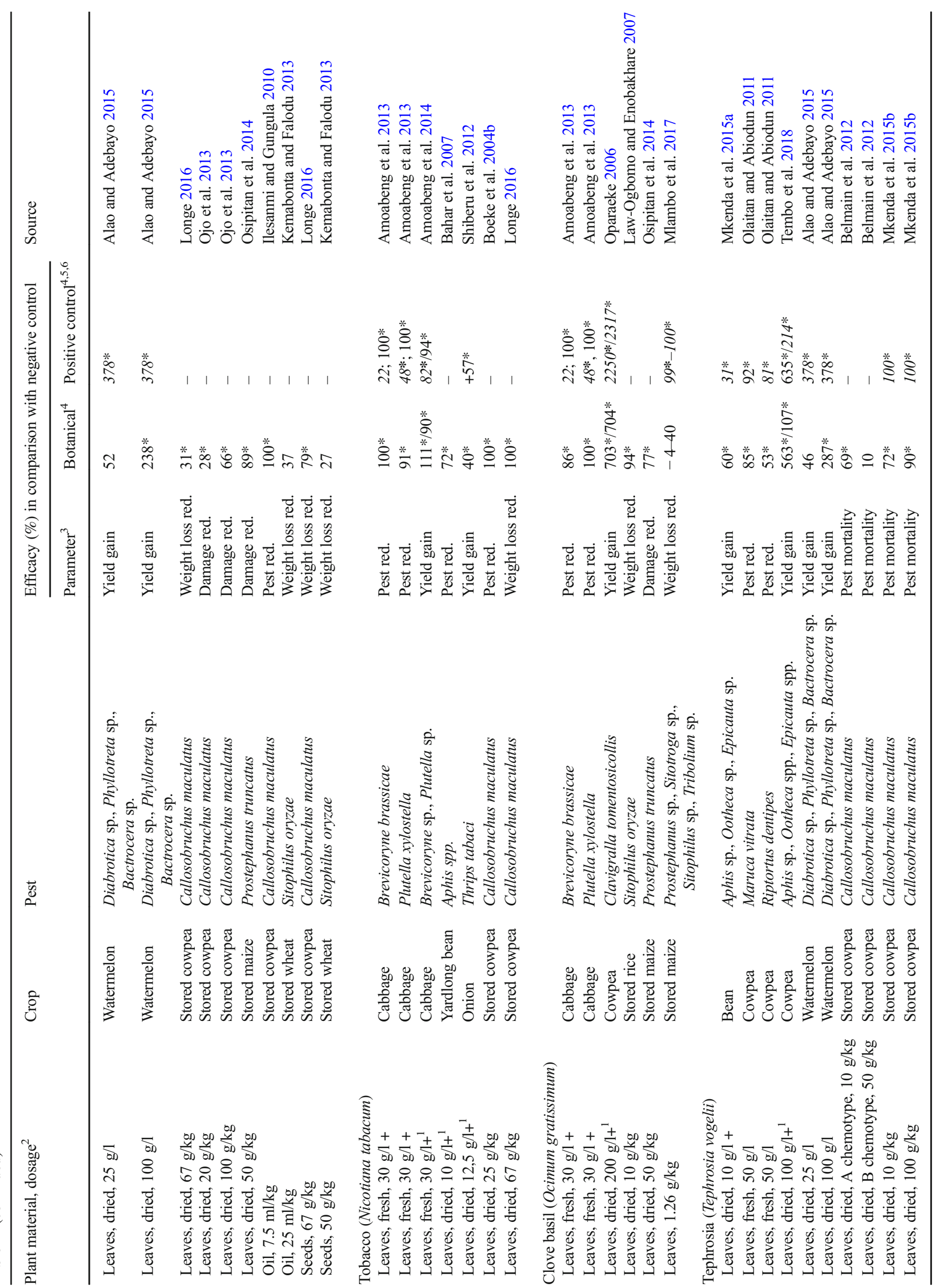




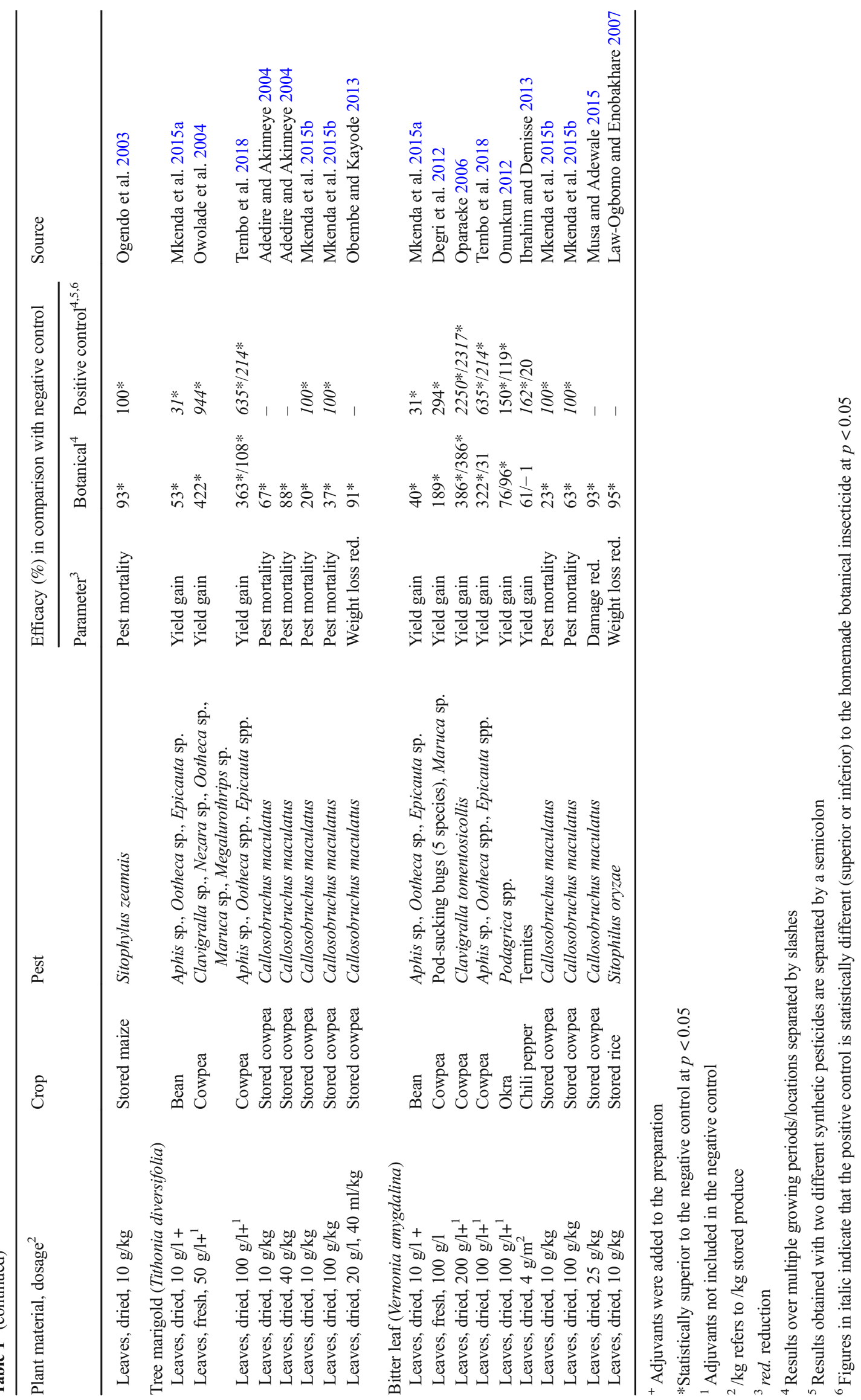




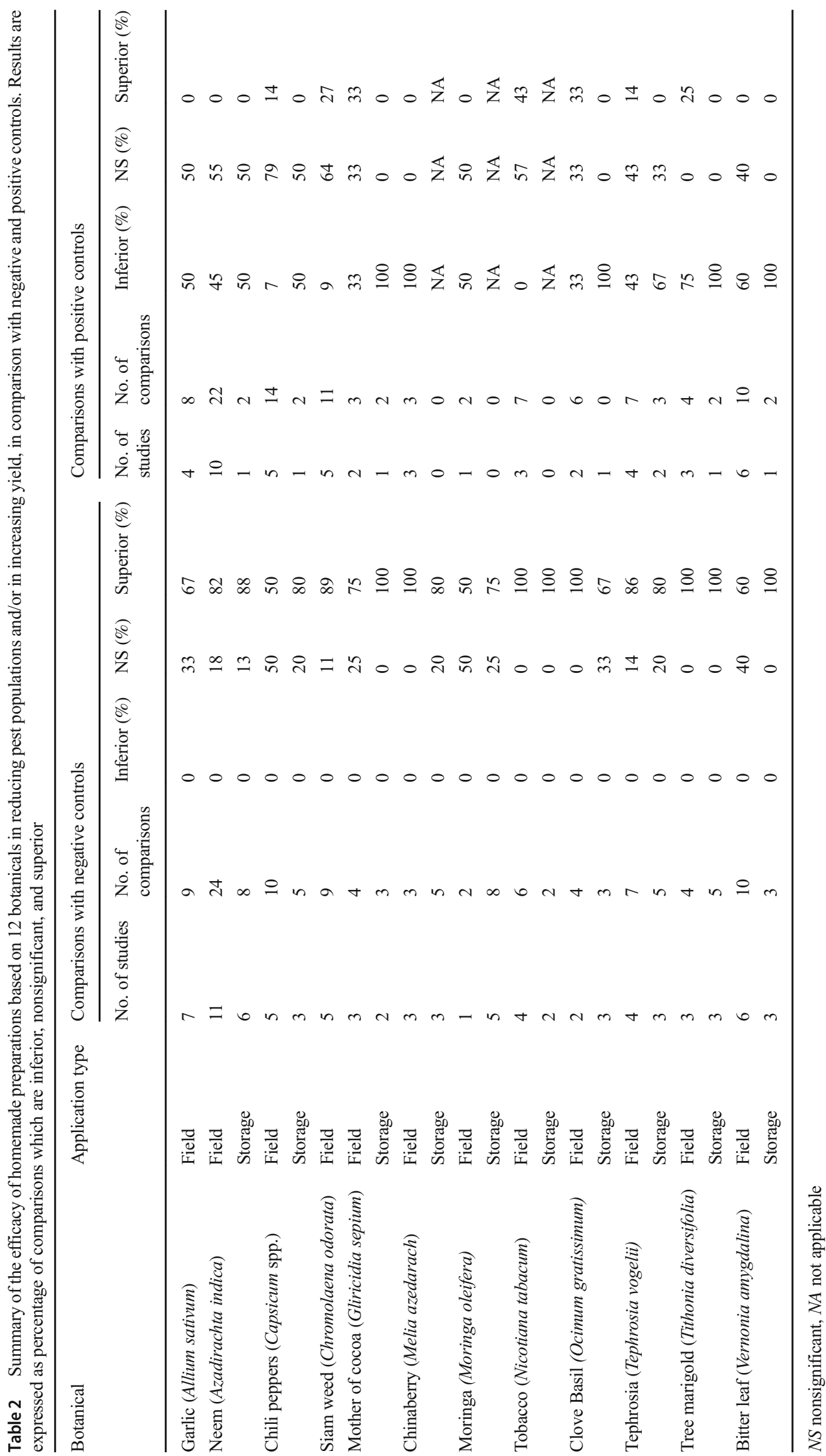




\section{Efficacy of homemade botanical insecticides}

\subsection{Garlic (Allium sativum)}

The pesticidal activity of garlic cloves has been attributed to sulfur-containing compounds that arise from the enzymatic degradation of allicin (Huang et al. 2000; Prowse et al. 2006; Yang et al. 2012; Zhao et al. 2013). Garlic extracts have been shown in laboratory trials to have acaricidal properties (Dąbrowski and Seredyńska 2007; Roobakkumar et al. 2010) and insecticidal properties against coleopteran, dipteran, lepidopteran, and hemipteran pests (Abdalla et al. 2017; Denloye 2010; Prowse et al. 2006; Yang et al. 2012; Zhao et al. 2013).

In field application trials, garlic aqueous extracts resulted in a varying level of control of hemipteran pests (Bahar et al. 2007; Baidoo and Mochiah 2016; Fening et al. 2013; Oparaeke et al. 2007; Said et al. 2015), lepidopteran pests (Baidoo and Mochiah 2016; Fening 2013; Oparaeke et al. 2007) as well as mites (Attia et al. 2011) (Table 1). Results were not significantly different in 3 out of 9 trials (Table 2), yet, in 1 trial, the 2 synthetic pesticides used as a positive control had no significant effect either. In comparison with positive controls, the efficacy of garlic aqueous extracts was statistically lower in half of the comparisons (Table 2). In 5 out of 7 studies, adjuvants were added to the preparations and those may have influenced their efficacy (see discussion for details). Other studies suggest that garlic-based homemade pesticides may be used to control mites on tomato (Kaputa et al. 2015) and fruit flies on watermelon (Degri and Sharah 2014), but the authors did not perform relevant statistical tests.

\subsection{Neem (Azadirachta indica)}

The insecticidal activity of neem has been attributed to limonoids. It is considered that azadirachtin A is the most active compound, but other limonoids may contribute to the efficacy of neem insecticides (Boursier et al. 2011; Isman et al. 1990; Lynn 2010; Nathan et al. 2005) and may even prevent resistance build-up against azadirachtin A (Feng and Isman 1995). Commercial extracts of neem are widely used for control of a wide range of insects as well as mites. The insecticidal and acaricidal properties of commercial neem-based products have been largely demonstrated (Morgan 2004).

Homemade aqueous extracts based on neem plant material (leaves, seeds, seed cake, and unformulated oil) have been successfully used for the control of blattodean pests (Ibrahim and Demisse 2013), hemipteran pests (Aziz et al. 2013; Degri et al. 2013; Gupta and Pathak 2009), lepidopteran pests (Abate 2011; Attia et al. 2011; Kumar et al. 2015; Okrikata et al. 2016), and thysanopteran pests (Shiberu et al. 2012) in field application (Tables 1 and 2). Out of 8 trials against lepidopteran pests, neem aqueous extracts showed efficacy in 7 trials. Foliar or soil application of neem aqueous extracts for insect pest control gave results superior to negative controls in 15 out of 18 instances and resulted in a yield increase in all 9 trials where yield was assessed. In comparison with synthetic pesticides, neem aqueous extracts were comparable in 10 out of 15 instances, but were inferior in 5 instances. The efficacy of neem aqueous extracts or of an oil emulsion against mite pests in field applications was documented only by Patil and Nandihalli (2009); both preparations reduced mite population, but did not impact yield. Efficacy of neem oil against fruit flies attacking watermelon has been reported, but appropriate statistics were not provided (Degri and Sharah 2014).

Ground neem plant material successfully and consistently controlled coleopteran pests in storage applications trials (Ahmad et al. 2015; Boeke et al. 2004b; Ileke and Oni 2011; Ilesanmi and Gungula 2010; Kemabonta and Falodu 2013; Kossou 1989). It did not provide any control in only 1 instance out of 8, although this may be explained by the low quantity of neem leaves used (Tables 1 and 2). The efficacy of ground neem in storage is supported by farmer participatory trials conducted by Paul et al. (2009) and earlier studies (Lale and Abdulrahman 1999; Pereira and Wohlgemuth 1982).

\subsection{Chili peppers (Capsicum spp.)}

Capsaicin is the main compound that gives chili peppers their spiciness. Capsaicin-rich commercial insecticide formulations are widely available. Capsaicin has repellent and insecticidal properties, for example, against hemipterans (Bergmann and Raupp 2014; Dayan et al. 2009). Antonious et al. $(2006,2007)$ indicate that other compounds may contribute to the insecticidal activity of preparations based on chili peppers.

In field application trials, chili pepper aqueous extracts have been used to control hemipteran pests (Amoabeng et al. 2013; Baidoo and Mochiah 2016; Fening et al. 2013, 2014), lepidopteran pests (Amoabeng et al. 2013; Baidoo and Mochiah 2016; Fening et al. 2013, 2014; Okrikata et al. 2016), and thysanopteran pests (Fening et al. 2014), yet the results obtained were inconsistent. Chili pepper aqueous extracts were superior to negative controls in 5 out of 10 instances. However, in 4 of the 5 trials where chili pepper aqueous extracts were ineffective, the synthetic pesticides used as positive control were also ineffective (Fening et al. 2013, 2014); therefore, those trials are not conclusive (Table 1). The positive controls were superior to chili pepper aqueous extracts only in 1 out of 14 instances, underlining that further research is needed for a conclusion.

In storage application trials, ground chili pepper fruits controlled the cowpea weevil Callosobruchus maculatus in 2 studies (Onu and Aliyu 1995; Yusuf et al. 2011) but was not effective in a third study (Boeke et al. 2004b) (Table 1). However, the efficacy of this practice is supported by farmer participatory trials conducted over 5 years in Ghana (Belmain and Stevenson 2001). Moreover, a study by Belmain et al. 
(1999) has shown that chili pepper was effective in killing and repelling various species of weevil attacking stored grains, although this publication does not provide exact figures.

\subsection{Siam weed (Chromolaena odorata)}

One of the main constituents of Siam weed's essential oil, the monoterpenoid $\alpha$-pinene, has insecticidal and repellent activities against coleopteran storage pests (Avlessi et al. 2012; Huang et al. 1998; Kim et al. 2010; Kossouoh et al. 2011; Owolabi et al. 2010). The insecticidal properties of the essential oil (Bouda et al. 2001) and extracts (Lawal et al. 2015) of Siam weed have been demonstrated on coleopteran pests in the laboratory.

In field applications, aqueous extracts of Siam weed controlled coleopteran pests (Onunkun 2012), lepidopteran pests (Amoabeng et al. 2013, 2014; Ezena et al. 2016), and hemipteran pests (Amoabeng et al. 2013, 2014; Degri et al. 2013; Ezena et al. 2016) (Table 1). Siam weed aqueous extracts were consistently ( 8 out of 9 instances) superior to negative controls and often comparable (7 out of 11 instances) to positive controls (Table 2). A study by Devi et al. (2013) suggested that Siam weed is effective in controlling mites on tea, but the authors did not provide statistical evidence.

\subsection{Mother of cocoa (Gliricidia sepium)}

Major secondary metabolites of mother of cocoa, coumarins, were reported to have insecticidal properties against coleopteran, dipteran, and lepidopteran pests as well as antifeedant properties against fall armyworm Spodoptera frugiperda (Kaniampady et al. 2007; Moreira et al. 2007; Vera et al. 2006). In the laboratory, extracts of mother of cocoa have been shown to possess insecticidal activities against coleopteran, dipteran, and lepidopteran insects (Parvathi and Jamil 1999; Sharma et al. 1998) as well as acaricidal activities (Sivira et al. 2011).

Mother of cocoa aqueous extracts controlled various insect pests (Montes-Molina et al. 2008a, 2008b) and mites (Jiménez-Martínez et al. 2016) in field application trials in 3 out of 4 instances (Tables 1 and 2). In storage applications, ground leaves of mother of cocoa controlled coleopteran pests, according to Ojo et al. (2013) and Rendón-Huerta et al. (2013).

\subsection{Chinaberry (Melia azedarach)}

Chinaberry contains limonoids, whose insecticidal and antifeedant properties have been demonstrated on coleopteran, dipteran, and lepidopteran pests in laboratory trials (Banchio et al. 2003; Carpinella et al. 2003; Chun Huang et al. 1995).
Aqueous extracts of both leaves and fruits controlled lepidopteran pests (McKenna et al. 2013; Singh et al. 2013) and mites (Attia et al. 2011) in the field, although efficacy was inferior to positive controls (Tables 1 and 2). Other studies indicated that aqueous extracts of chinaberry may be used to control serpentine leaf miners on Swiss chard (Abou-Fakhr Hammad et al. 2000) and cabbage aphids on cabbage (Kibrom et al. 2012), but the authors did not provide statistical details.

In storage applications, Chinaberry ground plant material has been successfully used for control of coleopteran storage pests in 2 studies (Espinoza et al. 2012; Hafez et al. 2014) and led to a reduction of grain damage (despite a nonsignificant effect on the pest population) in a third study conducted by Rendón-Huerta et al. (2013) (Tables 1 and 2).

\subsection{Moringa (Moringa oleifera)}

Lectins in moringa seeds have larvicidal activity on the mosquito Aedes egypti and on the flour moth Anagasta kuehniella (Agra-Neto et al. 2014; de Oliveira et al. 2011). Laboratory trials performed by Kamel (2010) on the fall armyworm S. frugiperda indicate that moringa seed oil has antifeedant and insecticidal properties.

The efficacy of moringa homemade botanical insecticide has been primarily assessed in storage applications, except in 1 study by Alao and Adebayo (2015) in which aqueous extracts of moringa controlled dipteran and coleopteran pests in the field (Tables 1 and 2). Ground moringa leaves controlled coleopteran pests during storage in 3 studies (Longe 2016; Ojo et al. 2013; Osipitan et al. 2014). However, results obtained with seed powder (Kemabonta and Falodu 2013; Longe 2016) and seed oil (Ilesanmi and Gungula 2010; Kemabonta and Falodu 2013) were inconsistent.

\subsection{Tobacco (Nicotiana tabacum)}

Tobacco owes its insecticidal properties to nicotine and other related alkaloids. Nicotine pesticides have a long history, but their use is decreasing because of its high toxicity to humans (Isman 2006).

Tobacco aqueous extracts controlled hemipteran pests (Amoabeng et al. 2013, 2014; Bahar et al. 2007), lepidopteran pests (Amoabeng et al. 2013, 2014), and thysanopteran pests (Shiberu et al. 2012), and their efficacy was comparable or superior to positive controls (Tables 1 and 2). In storage applications, the efficacy of ground tobacco leaves was documented in only by Boeke et al. 2004b and Longe 2016, with an efficacy of $100 \%$ against cowpea weevils in both studies. 


\subsection{Clove basil (Ocimum gratissimum)}

Clove basil essential oil and of some of its constituents have insecticidal and repellent activities against coleopteran pests and are repellents to houseflies in laboratory trials (Kéita et al. 2001; Ogendo et al. 2008; Ouedraogo et al. 2016; Singh and Singh 1991).

Homemade aqueous extracts of clove basil controlled hemipteran pests (Amoabeng et al. 2013; Oparaeke 2006) and lepidopteran pests (Amoabeng et al. 2013) in field applications (Tables 1 and 2). Results of storage trials are inconsistent, with 1 out of 3 trials showing no efficacy against coleopteran pests (Law-Ogbomo and Enobakhare 2007; Mlambo et al. 2017; Osipitan et al. 2014). However, the efficacy of clove basil in storage applications is supported by farmer participatory trials (Belmain and Stevenson 2001), indicating the adequacy of this botanical for storage applications.

\subsection{Tephrosia (Tephrosia vogelii)}

Tephrosia contains rotenoids, to which it owes its insecticidal properties (Isman 2008; Stevenson et al. 2012). Rotenone has been used as an insecticide for over 150 years (Isman 2008).

In field applications, tephrosia aqueous extracts have been used successfully to control coleopteran pests (Alao and Adebayo 2015; Mkenda et al. 2015a; Tembo et al. 2018), dipteran pests (Alao and Adebayo 2015), hemipteran pest (Mkenda et al. 2015a; Tembo et al. 2018), and lepidopteran pests (Olaitan and Abiodun 2011) (Table 1). In comparison with positive controls, the efficacy was often similar or inferior (3 instances each), but was superior in 1 instance (Table 2).

In storage applications, tephrosia ground leaf material controlled coleopteran pests (mortality rates of $69 \%$ and above) in 4 out of 5 instances (Belmain et al. 2012; Mkenda et al. 2015b; Ogendo et al. 2003). The 1 trial with a negative result had used a rotenoid-poor chemotype, underlining the importance of plant material selection (Belmain et al. 2012). The potential of tephrosia for storage application is supported by trials performed by Ogendo et al. (2004). In comparison with the positive controls, ground tephrosia leaves were less effective in 2 out of 3 comparisons. Results of this study were provided as charts with no numerical values and could thus not be included in the summary tables.

\subsection{Marigold tree (Tithonia diversifolia)}

A major constituent of marigold tree essential oil, the monoterpenoid $\alpha$-pinene, has insecticidal and repellent activities against coleopteran storage pests (Huang et al. 1998; Moronkola et al. 2006). Sesquiterpene lactones in tree marigold have been shown to be toxic to the coleoptera Callosobruchus maculatus (Green et al. 2017).
In field applications, marigold tree aqueous extracts have been successfully used against hemipteran pests (Mkenda et al. 2015a; Owolade et al. 2004; Tembo et al. 2018), coleopteran pests (Mkenda et al. 2015a; Owolade et al. 2004), or lepidopteran and thysanopteran pests (Owolade et al. 2004), resulting in increased yield in all 3 studies (Tables 1 and 2). In storage applications, ground tree marigold leaves controlled the cowpea weevil in all 3 studies, although the efficacy varied (Adedire and Akinneye 2004; Mkenda et al. 2015b; Obembe and Kayode 2013).

\subsection{Bitter leaf (Vernonia amygdalina)}

Sesquiterpene lactones with insecticidal activities against coleopteran pests and with repellent activities against lepidopteran pests have been isolated from bitter leaf (Ganjian et al. 1983; Green et al. 2017).

In field applications, bitter leaf aqueous extracts were used to control coleopteran pests (Mkenda et al. 2015a; Tembo et al. 2018), hemipteran pests (Degri et al. 2012; Mkenda et al. 2015a; Oparaeke 2006; Onunkun 2012; Tembo et al. 2018), and lepidopteran pests (Degri et al. 2012), with a positive outcome in 6 out of 8 instances and with a level of control inferior or similar to the positive controls (Tables 1 and 2). However, the application of ground plant material to the soil was not effective against termites (Ibrahim and Demisse 2013). In storage applications, bitter leaf ground plant material was used to control coleopteran storage pest (Law-Ogbomo and Enobakhare 2007; Mkenda et al. 2015b; Musa and Adewale 2015), with a positive outcome in all 4 instances (Tables 1 and 2).

\section{Interpreting the results}

\subsection{Assessing efficacy}

Efficacy of commercial pesticide products is assessed as part of the registration process. According to the guidelines published by the Food and Agriculture Organization of the United Nations (FAO 2006), this should include the testing of pesticides in comparison with a negative control and to a positive control, i.e., a reference product such as a synthetic standard pesticide or a standardized botanical extract. For major pest/crop combinations, these guidelines recommend at least 8 fully supportive trials (or more should the results be inconsistent) conducted over at least two seasons, but fewer trials are acceptable for minor pests or crops. Minimal efficacy levels should not be cast in stone, and low efficacy levels may be acceptable as long as they provide benefits to the grower, in particular if the product has no or low risk to nontarget species. Negative impacts on the target crop (yield or quality reductions), risks of resistance build-up, and other 
risks for agronomic sustainability should be included in the efficacy evaluation. Commercial pesticides based on some of the botanicals covered in this review (e.g., neem, garlic, chili pepper) are available and are generally tested this way. However, no homemade botanical insecticide has been tested in this way. As shown in Table 1, the efficacy studies compiled in this review at best included trials conducted over two growing periods or in two separate locations.

As Table 1 shows, there is a limited number of publications documenting the efficacy of a given botanical on a specific pest or pest/crop combination. The efficacy of the control achieved by homemade botanical insecticides was generally inconsistent among trials (Tables 1 and 2). This may be attributed to the variability in secondary metabolite (active ingredients) content or concentration in the plant material used or the processing and application methods, as illustrated by Kamanula et al. (2017) and by Stevenson et al. (2012). Yet, this should not obscure that, in a local context, a homemade botanical insecticide produced using a defined procedure and using plant material from a constant source could possibly produce consistently reliable results.

In the compiled studies, the chemical characterization of the plant material used was rarely performed and quantification of the active ingredients was performed only once, and this is in line with earlier observations made by Isman and Grieneisen (2014). Inconsistencies may also have arisen from the misidentification of botanicals. Indeed, plant names vary across locations, and the same local name may be used for similar yet distinct botanicals. This could be avoided by comparing gathered botanicals with type specimens documented in herbariums (Belmain and Stevenson 2001). For each botanical considered in this review, the trial methodology varied among the studies cited, e.g., plant part used, dosage, adjuvants, target host and pest, or the preparation method. Hence, the cited references are difficult to compare and can only be considered as indicative. This underlines that, although this review gives a highly valuable insight into the potential of homemade botanical insecticide for arthropod pest control, further research would be needed to validate which specific pests can effectively be targeted by a selected botanical.

\subsection{Absence of evidence is not evidence of absence}

This analysis suggests that homemade insecticides based on all 12 selected botanicals may or may not provide, under different circumstances, control of arthropod pests. Homemade botanical insecticides based on other botanicals have provided control of pests, such as Mexican tea, Dysphania ambrosioides L. (Asterales: Asteraceae) (Mazzonetto et al. 2013; Mkenda et al. 2015b; Pamela Nuñez et al. 2010; Paul et al. 2009; Tapondjou et al. 2003) or billygoat weed, Ageratum conyzoides (L.) Mosyakin \& Clements (Caryophyllales: Amaranthaceae) (Amoabeng et al. 2013,
2014; Kar et al. 2008; Onunkun 2012; Singh et al. 2013). However, this review was conditioned by the availability of literature. Negative results may not have been published, and this may have biased our analysis in two different ways: by overevaluating the efficacy of the botanicals included in this review or by making it impossible to include further and potentially ineffective botanicals because of a lack of literature. This last hypothesis is supported by farmer participatory trials conducted by Belmain and Stevenson (2001) and laboratory trials performed by Boeke et al. (2004b) indicating that a significant proportion of the botanicals used by farmers may have no or little efficacy.

\section{Factors affecting efficacy}

\subsection{Variation in active ingredient in botanical plant material}

A wide range of factors affects secondary metabolite content and concentration in plants and thus the concentration of active ingredients in botanical insecticicdes. Different plant parts are highly variable in active ingredient content and concentration. The plant's genotype, a wide range of environmental factors, and the development stage of the plant can strongly affect both content and concentration (Canter et al. 2005; Figueiredo et al. 2008; Gahukar 2014). Among the 12 botanicals included in this study, this has been particularly documented for neem (Elteraifi and Hassanali 2011; Gahukar 2014; Prakash et al. 2005; Sidhu et al. 2003; Yakkundi et al. 1995), Siam weed (Avlessi et al. 2012; Kossouoh et al. 2011), and tephrosia (Stevenson et al. 2012), but can be expected to be relevant for all botanicals. Such variations can dramatically impact the efficacy of homemade botanical insecticides. For example, at least one chemotype of tephrosia is totally ineffective (Belmain et al. 2012). Furthermore, active ingredients may break down over time, and this may be affected by storage conditions, as reported with neem seeds (Yakkundi et al. 1995). Three strategies have been suggested to reduce variation in active ingredient content and concentration in plant material: the collection of plant material from a large number of plants (Mkenda et al. 2015a); the selection and propagation of plant material with an appropriate content and an elevated concentration of secondary metabolites (Belmain et al. 2012; Canter et al. 2005); or the identification of optimal harvest timing (Yakkundi et al. 1995).

\subsection{Processing and adjuvants}

The method of processing homemade botanical insecticides can impact their efficacy in numerous ways, yet this is not well documented. Boursier et al. (2011) showed that a neem seed aqueous extract whose active ingredient concentration is 
much higher than recommended for commercial products could be obtained using a seed dosage typical of a traditional Malian recipe. Yet, they also showed how azadirachtin content in the extract may be influenced by factors such as extraction time and process or the shelling of the kernels prior to grinding. Some traditional preparation methods may be suboptimal. For instance, whole leaves of botanical source plants are often mixed directly with grains for protection during storage even though pulverization is considered to enhance efficacy (Belmain and Stevenson 2001).

The addition of adjuvants such as surfactants or stickers to pesticides is a common practice and is aimed at enhancing their efficacy through better coverage and longer persistence (Witt 2012). Similarly, small quantities of vegetable oil and/or soap or starch are often added during the preparation of aqueous extracts and before or after extraction. These are thought to improve extraction or coverage of the foliage (Kaputa et al. 2015; Mochiah et al. 2011). Authors added adjuvants to aqueous extracts in about half of the reviewed studies, and this may have had an influence on efficacy.

The most widely used adjuvant was soap, either as bar flakes or liquid soap. Laboratory trials have shown that small concentrations of household soap diluted in distilled water may have an outstanding insecticidal activity (Lee et al. 2006; Liu and Stansly 2000). Although field trials indicate that small concentrations of household soap $(1 \mathrm{ml} / \mathrm{l})$ do not statistically significantly affect pest populations (Amoabeng et al. 2014; Mkenda et al. 2015a), higher amounts of soap will likely do so. Besides its direct action on insects, soap also affects surface tension of spray mixture and should thus logically improve coverage and therefore efficacy of the active ingredient. Furthermore, enhanced extraction has also been reported using a surfactant $(10 \mathrm{ml} / \mathrm{l})$ for extraction of rotenoids from tephrosia plant material, indicating that the addition of an easily available surfactant such as soap would enhance the extraction of less polar compounds, such as azadirachtin (Belmain et al. 2012; Morgan 2009).

\subsection{Complex interactions and implications}

The efficacy of insecticides is commonly understood as their ability to kill a target pest. Some botanicals, such as pyrethrum or tobacco, contain compounds that have a neurotoxic activity, causing the rapid death of arthropod pests. However, a large number of botanicals and their compounds act in a more subtle way. For instance, azadirachtin, the main active ingredient of neem, affects the metabolism of insects, leading to female infertility and disruption of the molting process. Neem and chinaberry, as well as other botanicals of the Lamiaceae and Asteraceae family, have been shown to possess antifeedant properties. Other botanicals, such as citronella (Cymbopogon spp.), have repellent properties (Isman 2006).
Some field trials with homemade botanical insecticides show that lower pest mortality may not always mean lower efficacy (Aziz et al. 2013; Charleston et al. 2006; Mkenda et al. 2015a; Montes-Molina et al. 2008a; Tembo et al. 2018). Natural enemies also play an important role in the reduction of pest populations, and the application of pesticides of either synthetic or natural origin can harm them (Cloyd 2012; Pimentel et al. 1992). Some botanical insecticides, such as bitter leaf, neem, tephrosia, and tree marigold, may have a low toxicity towards natural enemies (Aziz et al. 2013; Mkenda et al. 2015a; Mkindi et al. 2017), and the use of such products can favorably shift the pest/natural enemy balance and result in a prolonged efficacy of the control intervention (Naranjo and Ellsworth 2009).

Some plant species used for the preparation of homemade botanical insecticides also have fungicidal and/or bactericidal properties, such as tephrosia (Owolade et al. 2004), neem (Hassanein et al. 2010), and Siam weed (Avlessi et al. 2012). Others may simultaneously act as a foliar fertilizer, such as mother of cocoa (Montes-Molina et al. 2008b). These properties may positively impact yields. On the other hand, some botanicals have been reported to have allelopathic properties, such as Siam weed (Sahid and Sugau 1993), so their use may negatively affect crop growth. These observations underline the importance of full-season field trials that take yield into account, as this allows a better understanding of how homemade botanical insecticides can contribute to preventing yield losses.

\section{Safety}

\subsection{Human safety}

Risks linked to pesticide use depend on their toxicity and on the exposure of applicators or consumers. Pesticides are normally assessed as part of the registration process. According to the guidelines published by the Food and Agriculture Organization of the United Nations and the World Health Organization, assessments shoud include the acute toxicity of formulated product in order to identify appropriate protective measures. The acute toxicity of the active ingredient and its metabolites or degradates should be assessed in order to identify health hazards linked to short-term exposure. Subchronic and chronic effects, mutagenicity, carcinogenicity, and reproductive and developmental toxicity should be assessed to identify the risks related to a long-term exposure. Moreover, exposure of farm workers and applicators, as well as residue in the crop produce, should be evaluated to define whether the risks linked to pesticide use are acceptable (FAO and WHO 2013, 2016). With the exception of neem products, such safety assessments have not been conducted with homemade botanical insecticides, or only partially. A major 
difference between homemade botanical insecticides and commercial pesticides is that the former contains a cocktail of active ingredients with unknown concentrations, as well as a long list of compounds with unknown properties in variable concentrations. Moreover, although concentration in plant material may be low, exposure during processing has not been assessed and may be high. As a result, even when safety assessments exist, the risks identified in laboratory trials are difficult to extrapolate to real-life situations. Plant protection legislation in many countries does not allow the use of homemade preparations, something that often contradicts the reality in farming. Therefore, some countries legally allow the use of such preparations, at least for noncommercial farming (Belmain and Stevenson 2001; Klein et al. 2015).

Neem products, in particular neem oil and aqueous extracts, have a low subchronic and chronic toxicity. Results of acute toxicity trials are more ambiguous but generally point to a low toxicity to mammals (Boeke et al. 2004a). Scattered data are available for other botanicals covered in this review. Aqueous ethanol extracts of Siam weed had a low mammalian toxicity in acute and subchronic toxicity trials (Ogbonnia et al. 2010). Clove basil and marigold tree essential oils and ethanolic and aqueous extracts have been shown to have an extremely low acute mammalian toxicity, and subchronic toxicity trials suggest that aqueous extracts of tree marigold are relatively safe (Kamatenesi-Mugisha et al. 2010; Passoni et al. 2013). Although these data need to be validated and complemented, the above plants have been used for centuries as a traditional medicine, and this supports the idea that they have a relatively low toxicity. Bitter leaf, chili pepper, garlic, and moringa are consumed as food or spice. The long use history of these botanicals indicates that their use as a pesticide represents minimal risk. Compounds occurring widely in food are granted the status of "Generally Recognized As Safe" by the Food and Drug Administration of the United States of America (FDA 2019). In contrast, tobacco contains nicotine, which has a high acute toxicity. Nicotine is classified as highly hazardous (class Ib) by the World Health Organization (WHO 2009), and nicotine pesticides are now banned in most countries. For this reason, Plantwise discourages the use of tobacco-based homemade botanical insecticides. Tephrosia contains rotenone, which is classified as moderately hazardous (class II) because of its acute toxicity and it has been linked to Parkinson's disease (Tanner et al. 2011; WHO 2009). Finally, ingestion of chinaberry is reported to have caused human and animal poisonings. However, some authors argue that active ingredient concentrations in plants like tephrosia and tobacco are low, and that the use of these botanicals for pest control by subsistence farmers is unlikely to cause intoxications (Belmain et al. 2012; Isman 2008).

Smallholder farmers who use homemade botanicals to control agricultural pests do so primarily for economic reasons but are also worried about potential health issues resulting from the use of synthetic pesticides (Belmain and Stevenson 2001; Isman 2017; Kamatenesi-Mugisha et al. 2008). Smallholder farmers who cannot afford to buy synthetic pesticides also will not be able to buy appropriate protective equipment. This underlines that more safety assessments should be conducted so that safe botanicals and preparation methods can be identified. Yet, certain homemade botanical insecticides may represent a relatively safe alternative. This is particularly relevant when considering that highly hazardous pesticides are still often used in low-income countries, resulting all too often in farmer poisonings (Grzywacz et al. 2014; Kesavachandran et al. 2009; Ngowi et al. 2007; Weinberger and Srinivasan 2009), thus incurring significant hidden societal costs (Bourguet and Guillemaud 2016; Soares and Porto 2012). Yet, the principle of precaution should be applied to homemade botanical insecticides. Exposure to botanicals known to pose a significant risk to human health should generally be avoided.

\subsection{Environmental safety}

In parallel to human health risks, adverse effects of pesticide use on nontarget organisms - such as natural enemies of pests, pollinators and also birds, fish, or mammals - depend on their toxicity and on exposure. These risks should be assessed as part of the registration process to define whether they are acceptable (FAO and WHO 2013, 2016). Data on environmental fate is also normally required for the registration of pesticides. Bioaccumulation is generally considered less likely to occur with homemade botanical insecticides as they contain naturally occurring substances, which are known to degrade more quickly than many synthetic compounds, as illustrated by natural pyrethrins vs. synthetic pyrethroids (Smith and Stratton 1986).

Thorough environmental safety assessments have not been conducted with most botanical insecticides as they are not as heavily regulated. The toxicity of commercial neem pesticides to natural enemies has been reviewed by El-Wakeil et al. (2013). The authors conclude that neem toxicity is usually significantly lower compared with synthetic pesticides, although some nontarget species may be particularly susceptible. The few available studies on the impacts of homemade botanical insecticides on nontarget species suggest that aqueous extracts often have a relatively lower impact on natural enemies compared with broad-spectrum insecticides. Aqueous extracts of Siam weed and tobacco had lower impacts on nontarget ladybirds, hoverflies, and spiders compared with emamectine benzoate (Amoabeng et al. 2013). In a trial conducted by Mkenda et al. (2015a), aqueous extracts based on tephrosia and tree marigold had no impact on ladybirds and limited or no impact on spiders. An aqueous extract based on bitter leaf had no impact on spiders but suppressed ladybird population to a degree similar to lambda-cyhalothrin. More 
recently, trials conducted by Mkindi et al. (2017) confirm the relatively low toxicity of tephrosia, tree marigold, and bitter leaf aqueous extracts on hover fly, lacewing, lady bird, and spider populations. Another example is provided by Singh et al. (2013), who observed that an aqueous extract of chinaberry had a lower impact on ladybird populations in comparison with malathion.

Data on pollinator toxicity of homemade botanical insecticides are also lacking (IOBC 2018). Laboratory trials indicate that commercial neem extract may be harmful to bees and wild pollinators (Bernardes et al. 2017), but no impact could be detected in the field (Naumann et al. 1994). Pure azadirachtin is classified to be moderately toxic to bees, and the use of the pesticides falling in this category is usually not recommended on blooming plants or areas that are visited by bees (Cluzeau 2002; Maciorowski 1994). A commercial garlic extract as well as rotenone-based product proved to have lethal and sublethal effects on bees but not on wild pollinators in laboratory trials (Xavier et al. 2010; Xavier et al. 2015). Rotenone is classified as relatively nontoxic to bees, and the use of the pesticides falling in this class is usually not restricted (Cluzeau 2002; Devillers 2002).

Other nontarget organisms include other arthropods, fungi, molluses, aquatic organisms, mammals, or birds, yet toxicity of homemade botanicals to these organisms is often not known. However, the use of tephrosia products for poison fishing illustrates the potential risk posed by homemade botanical insecticides to the environment (Neuwinger 2004; Pubchem 2018).

These data highlight that, despite the fact that some homemade botanical insecticides may have lower toxicity to nontarget species compared with broad-spectrum insecticides, harmful effects have been observed, underlining the need for further research. The application of botanicals should thus be guided by necessity and done with care, taking their potential negative impact to nontarget species into consideration. Likewise, just as pesticides should not be used as the only pest management intervention, botanicals should not be used in isolation either. Botanicals can fit into an IPM system. For example, botanicals can be used in combination with crop diversification, habitat management, and other nonpesticide tools.

\subsection{Risks to biodiversity}

Some of the plants used for the preparation of homemade botanical insecticides are invasive species, such as tree marigold and Siam weed (CABI 2017). The collection in cultivated areas or in the wild may perhaps contribute to reduce the populations of these invasive species. Yet, their cultivation for the purpose of producing botanical insecticides may contribute to their expansion and further increase the negative impact of these invasive species on biodiversity and on the livelihoods of farmers. This also means that botanicals used in homemade insecticides and known to be invasive should never be introduced into areas where they are presently absent.

\section{Economic viability and practicality}

Before botanicals can be processed, they must be grown, collected in nature, or bought from the market. Processing may require a heavy workload, and homemade botanical insecticides may require more frequent applications than synthetic pesticides. Benefit/cost impact studies, which take into account the total costs, including labor of homemade botanical insecticide preparation and application, give an insight into their economic viability.

The total costs are often reported to be substantially lower compared with the cost of buying and applying a commercial chemical pesticide (Gupta 2005; Gupta and Pathak 2009; Mkenda et al. 2015a). In 1 case, the total costs of homemade botanical insecticides were comparable with the synthetic pesticide (Amoabeng et al. 2014); however, this is mainly because the local daily wage used in this study was 8.33 USD, which is considerably more than the daily income of many subsistence farmers in the world (FAO 2015).

Among the botanicals selected for this review, benefit/cost ratios have been calculated for field applications use of homemade botanical insecticides based on 7 of the 12 botanicals. This is most well documented in a number of studies on neem homemade botanical insecticides that found profitable benefit/ cost ratios: using leaves, seed kernels, seed cake, or oil for control of (1) the green leafhopper Nephotettix virescens in rice (Rajappan et al. 2000), (2) the aphid Sitobion aveanae in wheat (Aziz et al. 2013), (3) the aphid Lipaphis erysimi in mustard (Gupta 2005), (4) the whitefly Bemisia tabaci and the pod borer Maruca testulalis in black gram (Gupta and Pathak 2009), (5) the pod bug Clavigralla gibbosa in pigeon pea (Narasimhamurthy and Ram 2013), and (6) the Sesamia calamistis stem borers in sorghum (Okrikata et al. 2016). The economic viability of homemade botanical insecticides based on other plant species is less well documented. Nonetheless, in all the reviewed studies, profitable benefit/ cost ratios have been obtained with homemade botanical insecticides. This includes Siam weed or tobacco for control of the diamondback moth Plutella xylostella and aphids Brevicoryne brassicae in cabbage (Amoabeng et al. 2014). Similar results have been obtained by Mkenda et al. (2015a) with aqueous extracts based on tephrosia, tree marigold, and bitter leaf in bean against the aphid Aphis fabae, the bean flower beetles Epicauta albovittata and E. limbatipennis, and the bean foliage beetles Ootheca nutabilis and $O$. bennigseni. A profitable benefit/cost ratio has also been obtained using ground chili pepper for control of Sesamia calamistis stem borers in sorghum (Okrikata et al. 2016). 
These results underline the economic viability of this management practice, but should not detract from the fact that commercial pesticides, although costly, may provide a better control of pests and a better net gain for the farmer at the end of the season. Nevertheless, independently of the time required for their production, some botanical preparations may represent an interesting alternative for resource-poor subsistence and transitional farmers who often simply cannot access or afford to buy synthetic pesticides.

\section{Conclusions}

The pest control methods using traditional knowledge are based on centuries-long empirical observations, but may also be tainted with belief. Our review shows that active ingredients with insecticidal properties have been isolated in all the botanicals covered by this study. The data indicate that homemade insecticides based on the 12 selected botanicals have the potential to lower arthropod pest populations or to reduce the losses they cause. Although synthetic pesticides may often be more effective, all existing benefit/cost studies support the economic viability of homemade botanical insecticides. This means that homemade botanical insecticides could be, in some cases, an acceptable alternative to commercial pesticides, particularly where availability of and access to synthetic pesticides are limited. Nonetheless, it must be acknowledged that the results of using homemade botanicals are highly unpredictable, as their effectiveness and safety have not been fully tested.

For every botanical included in this study, the efficacy varied among trials, and, in some cases, the use of homemade botanical insecticides neither resulted in a reduction of pest populations nor prevented crop losses. This can be attributed to variation in active ingredient content or concentration in plant material, variation in the preparation method, or also variation in the conditions and the way in which they were tested. National researchers in some countries are already working on improving homemade botanical insecticide efficacy through plant material selection and optimized processing. These efforts should be encouraged and supported so that the locally appropriate, optimized, and standardized homemade botanical insecticide preparation methods can be disseminated to subsistence and transitional farmers. In addition, research on the possible health risks related to the use of botanicals ought to be better financed, and national pesticide legislation could be adapted to more formally address the benefits and risks associated with homemade botanicals.

Neem products have a low human toxicity and an acceptable environmental toxicity, and their use can thus be considered as relatively safe. However, human and environmental risks of other botanicals often have not been sufficiently assessed using standardized procedures, and this deserves further investigation. Some botanicals used for the preparation of homemade insecticides are consumed as food or traditional medicine, which suggests that their use should pose limited risk. Yet, the possible consequences of extensive and prolonged exposure to homemade botanical insecticides are unknown. Use of botanicals known to be toxic, e.g., tobacco, should be avoided. As a precaution, personal protective equipment should be worn during the preparation and application of homemade botanical insecticides, irrespective of which botanical is used.

The use of homemade botanical insecticides is so widespread in low-income countries that it should not be ignored. Homemade botanical insecticides may be less effective than synthetic pesticides but, in particular when used within an IPM approach, constitute an option for farmers who have no access to commercial pesticides or who cannot afford them. Thus, they contribute to reducing losses during food production in the most underprivileged regions of the world. It is just important that those promoting the use of these homemade botanical insecticides are aware of and also communicate the uncertainties around the use of these products (i.e., variable efficacy and potential effects on health and the environment). This review provides an in-depth analysis of the potential and limitations of homemade botanical insecticides and defines areas for further research.

Acknowledgments We would like to thank Janny Vos (CABI) and two anonymous reviewers for their feedback on an earlier version of this manuscript.

Funding Plantwise is funded and supported by the UK Department for International Development (DfID), the Swiss Agency for Development Cooperation (SDC), the European Commission (DG DEVCO), the Netherlands Ministry of Foreign Affairs (DGIS), the Irish Aid, the International Fund for Agricultural Development (IFAD), and the Australian Centre for International Agricultural Research (ACIAR). See https://www.cabi.org/about-cabi/who-we-work-with/key-donors/ for details.

\section{Compliance with ethical standards}

Conflict of interest The authors declare that they have no conflict of interest.

Open Access This article is distributed under the terms of the Creative Commons Attribution 4.0 International License (http:// creativecommons.org/licenses/by/4.0/), which permits unrestricted use, distribution, and reproduction in any medium, provided you give appropriate credit to the original author(s) and the source, provide a link to the Creative Commons license, and indicate if changes were made.

\section{References}

Abate T (2011) Maize stalk borers of Ethiopia: quantitative data on ecology and management. In: Proceedings of the 3rd National Maize Workshop of Ethiopia. CIMMYT, Mexico, pp. 174-184 
Abate T, van Huis A, Ampofo JK (2000) Pest management strategies in traditional agriculture: an African perspective. Annu Rev Entomol 45:631-659. https://doi.org/10.1146/annurev.ento.45.1.631

Abbott WS (1925) A method of computing the effectiveness of an insecticide. J Econ Entomol 18:265

Abdalla MI, Abdelbagi AO, Hammad AMA, Laing MD (2017) Use of volatile oils of garlic to control the cowpea weevil Callosobruchus maculatus (Bruchidae : Coleoptera). S Afr J Plant Soil 34(3):185

Abou-Fakhr Hammad EM, Nemer NM, Kawar NS (2000) Efficacy of chinaberry tree (Meliaceae) aqueous extracts and certain insecticides against the pea leafminer (Diptera: Agromyzidae). J Agric Sci 134(4):413. https://doi.org/10.1017/S002185969900773X

Adedire CO, Akinneye JO (2004) Biological activity of tree marigold, Tithonia diversifolia, on cowpea seed bruchid, Callosobruchus maculatus (Coleoptera : Bruchidae). Ann Appl Biol 144(2):185. https://doi.org/10.1111/j.1744-7348.2004.tb00332.x

Agra-Neto AC, Napoleão TH, Pontual EV, Santos DN, de Luz AL, de Oliveira CM, de Melo-Santos MA, Coelho LC, Navarro DM, Paiva PM (2014) Effect of Moringa oleifera lectins on survival and enzyme activities of Aedes aegypti larvae susceptible and resistant to organophosphate. Parasitol Res 113(1):175. https://doi.org/10.1007/ s00436-013-3640-8

Ahmad T, Haile A, Ermias A, Etbarek R, Habteab S, Teklai S (2015) Ecofriendly approaches for management of bruchid beetle Callosobruchus chinensis (Coleoptera: Bruchidae) infesting faba bean and cowpea under laboratory conditions. J Stored Prod Postharvest Res 6(3):25. https://doi.org/10.5897/JSPPR2014.0179

Alao FO, Adebayo TA (2015) Comparative efficacy of Tephrosia vogelii and Moringa oleifera against insect pests of watermelon (Citrullus lanatus Thumb). Int Lett Nat Sci 35:71. https://doi.org/10.18052/ www.scipress.com/ILNS.35.71

Amoabeng BW, Gurr GM, Gitau CW, Nicol H, Munyakazi L, Stevenson PC (2013) Tri-trophic insecticidal effects of African plants against cabbage pests. PLoS One 8(10):e78651. https://doi.org/10.1371/ journal.pone.0078651

Amoabeng BW, Gurr GM, Gitau CW, Stevenson PC (2014) Cost : benefit analysis of botanical insecticide use in cabbage: implications for smallholder farmers in developing countries. Crop Prot 57:71. https://doi.org/10.1016/j.cropro.2013.11.019

Antonious GF, Meyer JE, Snyder JC (2006) Toxicity and repellency of hot pepper extracts to spider mite, Tetranychus urticae Koch. J Environ Sci Health B 41(8):1383. https://doi.org/10.1080/ 0360123060096419

Antonious GF, Meyer JE, Rogers JA, Hu Y-H (2007) Growing hot pepper for cabbage looper, Trichopulsia ni (Hubner) and spider mite, Tetranychus urticae (Koch) control. J Environ Sci Health B 42(5): 559. https://doi.org/10.1080/03601230701389512

Attia S, Lebdi Grissa K, Ghrabi-Gammar Z, Mailleux AC, Lognay G, Le Goff G, Hance T (2011) Contrôle de Tetranychus urticae par les extraits de plantes en vergers d'agrumes. Faunistic Entomol 63(4): 229

Avlessi F, Alitonou GA, Djenontin ST, Tchobo F, Yèhouénou B, Menut C, Sohounhloué D (2012) Chemical composition and biological activities of the essential oil extracted from the fresh leaves of Chromolaena odorata (L. Robinson) growing in Benin. Int Res J Biol Sci 1(3):7

Aziz MA, Ahmad M, Nasir MF (2013) Efficacy of different neem (Azadirachta indica) products in comparison with Imidacloprid against English grain aphid (Sitobion avenae) on wheat. Int $\mathbf{J}$ Agric Biol 15(2):279

Bahar H, Islam A, Mannan A, Uddin J (2007) Effects of some botanical extracts on bean aphids attacking yard-long beans. J Entomol 4(2): 136

Baidoo PK, Mochiah MB (2016) Comparing the effectiveness of garlic (Allium sativum L.) and hot pepper (Capsicum frutescens L.) in the management of the major pests of cabbage Brassica oleracea (L.). Sustain Agric Res 5(2):83. https://doi.org/10.5539/sar.v5n2p83

Banchio E, Valladares G, Defago M, Palacios S, Carpinella C (2003) Effects of Melia azedarach, (Meliaceae) fruit extracts on the leafminer Liriomyza huidobrensis, (Diptera, Agromyzidae): assessment in laboratory and field experiments. Ann Appl Biol 143(2): 187. https://doi.org/10.1111/j.1744-7348.2003.tb00285.x

Belmain S, Stevenson PC (2001) Ethnobotanicals in Ghana: reviving and modernising age-old farmer practice. Pestic Outlook 12(6):233. https://doi.org/10.1039/b110542f

Belmain S, Golob P, Andan HF, Cobbinah JR (1999) Ethnobotanicalsfuture prospects as post-harvest insecticides. Agro Food Ind Hi-tech 10(5):34

Belmain SR, Amoah BA, Nyirenda SP, Kamanula JF, Stevenson PC (2012) Highly variable insect control efficacy of Tephrosia vogelii chemotypes. J Agric Food Chem 60(40):10055. https://doi.org/10. 1021/jf3032217

Bergmann EJ, Raupp MJ (2014) Efficacies of common ready to use insecticides against Halyomorpha halys (Hemiptera : Pentatomidae). Florida Entomol 97(2):791. https://doi.org/10. 1653/024.097.0262

Bernardes RC, Tomé HVV, Barbosa WF, Guedes RNC, Lima MAP (2017) Azadirachtin-induced antifeeding in Neotropical stingless bees. Apidologie 48(3):275. https://doi.org/10.1007/s13592-0160473-3

Boeke SJ, Boersma MG, Alink GM, van Loon JJA, van Huis A, Dicke M, Rietjens IMCM (2004a) Safety evaluation of neem (Azadirachta indica) derived pesticides. J Ethnopharmacol 94(1):25. https://doi. org/10.1016/j.jep.2004.05.011

Boeke SJ, Baumgart IR, van Loon JJA, van Huis A, Dicke M, Kossou DK (2004b) Toxicity and repellence of African plants traditionally used for the protection of stored cowpea against Callosobruchus maculatus. J Stored Prod Res 40(4):423. https://doi.org/10.1016/ S0022-474X(03)00046-8

Bouda H, Tapondjou LA, Fontem DA, Gumedzoe MYD (2001) Effect of essential oils from leaves of Ageratum conyzoides, Lantana camara and Chromolaena odorata on the mortality of Sitophilus zeamais (Coleoptera, Curculionidae). J Stored Prod Res 37(2):103. https:// doi.org/10.1016/S0022-474X(00)00011-4

Bourguet D, Guillemaud T (2016) The hidden and external costs of pesticide use. In: Sustainable agriculture reviews: volume 19, 1st edn. Springer International Publishing, Cham, pp 35-120

Boursier CM, Bosco D, Coulibaly A, Negre M (2011) Are traditional neem extract preparations as efficient as a commercial formulation of azadirachtin A? Crop Prot 30(3):318. https://doi.org/10.1016/j. cropro.2010.11.022

CABI (2017) Invasive species compendium. Centre for Agriculture and Biosciences International. http://www.cabi.org/isc/. Accessed 13 February 2017

Canter PH, Thomas H, Ernst E (2005) Bringing medicinal plants into cultivation: opportunities and challenges for biotechnology. Trends Biotechnol 23(4):180. https://doi.org/10.1016/j.tibtech.2005.02.002

Carpinella MC, Defago MT, Valladares G, Palacios SM (2003) Antifeedant and insecticide properties of a limonoid from Melia azedarach (Meliaceae) with potential use for pest management. J Agric Food Chem 51(2):369. https://doi.org/10.1021/jf025811w

Charleston DS, Kfir R, Dicke M, Vet LEM (2006) Impact of botanical extracts derived from Melia azedarach and Azadirachta indica on populations of Plutella xylostella and its natural enemies: a field test of laboratory findings. Biol Control 39(1):105. https://doi.org/10. 1016/j.biocontrol.2006.05.012

Chun Huang R, Zhou J-B, Suenaga H, Takezaki K, Tadera K, Nakatani M (1995) Insect antifeeding property of limonoids from Okinawan and Chinese Melia azedarach L., and from Chinese Melia toosendan (Meliaceae). Biosci Biotechnol Biochem 59(9):1755. https://doi. org/10.1271/bbb.59.1755 
Cloyd RA (2012) Indirect effects of pesticides on natural enemies. In: Pesticides - advances in chemical and botanical pesticides. InTech, London, pp 127-150

Cluzeau S (2002) Risk assessment of plant protection products on honey bees: regulatory aspects. In: Honey bees: estimating the environmental impact of chemicals. Taylor \& Francis, London, pp 40-55

Dąbrowski ZT, Seredyńska U (2007) Characterisation of the two-spotted spider mite (Tetranychus urticae, Koch ) response to aqueous extracts from selected plant species. J Plant Prot Res 47(2):113

Dayan FE, Cantrell CL, Duke SO (2009) Natural products in crop protection. Bioorg Med Chem 17(12):4022. https://doi.org/10.1016/j. bmc.2009.01.046

Degri MM, Sharah HS (2014) Field evaluation of two aqueous plant extracts on water melon Citrullus lanatus (Thumb) insect pets in northern Guinea Savannah of Nigeria. Int Lett Nat Sci 9:59

Degri MM, Maina YT, Richard BI (2012) Effect of plant extracts on post flowering insect pests and grain yield of cowpea (Vigna unguiculata L.Walp.) in Maiduguri, semi arid zone of Nigeria. J Biol Agric Healthc 2(3):46

Degri M, Mailafiya D, Wabekwa J (2013) Efficacy of aqueous leaf extracts and synthetic insecticide on pod-sucking bugs infestation of cowpea (Vigna unguiculata (L.) Walp) in the Guinea Savanna Region of Nigeria. Adv Entomol 01(02):10. https://doi.org/10. 4236/ae.2013.12003

Denloye AA (2010) Bioactivity of powder and extracts from garlic, Allium sativum L. (Alliaceae) and spring onion, Allium fistulosum L. (Alliaceae) against Callosobruchus maculatus F. (Coleoptera : Bruchidae) on cowpea, Vigna unguiculata (L.) Walp (Leguminosae) seeds. Psyche: J Entomol 2010(2):1. https://doi. org/10.1155/2010/958348

Devi OI, Dutta BK, Choudhury P (2013) Control of red spider mite (Oligonychus coffeae, Nietner) in tea [Camellia sinensis L. (O) Kuntze] plantation of Barak Valley (Southern Assam) using allelopathic plant extracts. Int J Tea Sci 9(4):25

Devillers J (2002) Acute toxicity of pesticides to honey bees. In: Honey bees: estimating the environmental impact of chemicals. Taylor \& Francis, London, pp 56-66

Dougoud J, Cock MJW, Edgington S, Kuhlmann U (2018) A baseline study using Plantwise information to assess the contribution of extension services to the uptake of augmentative biological control in selected low- to lower-middle-income countries. BioControl 63(1): 117. https://doi.org/10.1007/s10526-017-9823-y

Elteraifi IE, Hassanali A (2011) Oil and azadirachtin contents of neem (Azadirachta indica A. Juss) seed kernels collected from trees growing in different habitats in Sudan. Int J Biol Chem Sci 5(3):1063. https://doi.org/10.4314/ijbcs.v5i3.72211

El-Wakeil N, Gaafar N, Sallam A, Volkmar C (2013) Side effects of insecticides on natural enemies and possibility of their integration in plant protection strategies. In: Insecticides - development of safer and more effective technologies. InTech, London, pp 3-56

Espinoza ME, Silva G, Tapia M, Rodríguez JC, Lagunes A, SantillánOrtega C, Robles-Bermúdez A, Aguilar-Medel S (2012) Insecticidal activity of Melia azedarach L. against Sitophilus zeamais Motschulsky (Coleoptera: Curculionidae). Agro-Ciencia 28(2):81

Ezena GN, Akotsen-Mensah C, Fening KO (2016) Exploiting the insecticidal potential of the invasive Siam weed, Chromolaena odorata L. (Asteraceae) in the management of the major pests of cabbage and their natural enemies in Southern Ghana. Adv Crop Sci Tech 4(4):230. https://doi.org/10.4172/2329-8863.1000230

FAO (2006) Interntional code of conduct on pesticide management: guidelines on efficacy evaluation for the registration of plant protection products. Food and Agriculture Organization of the United Nations. http://www.fao.org/fileadmin/templates/agphome/ documents/Pests Pesticides/Code/Efficacy.pdf. Accessed 9 January 2018
FAO (2013) Statistical yearbook of the Food and Agricultural Organization of the United Nations. Food and Agriculture Organization of the United Nations. http://www.fao.org/docrep/ 018/i3107e/i3107e01.pdf. Accessed 26 January 2017

FAO (2015) The economic lives of smallholder farmers. Food and Agriculture Organization of the United Nations. http://www.fao. org/3/a-i5251e.pdf. Accessed 31 March 2017

FAO, WHO (2013) International code of conduct on pesticide management: Guidelines on data requirements for the registration of pesticides. Food and Agriculture Organization of the United Nations; World Health Organization. www.fao.org/3/a-bc870e.pdf. Accessed 9 January 2018

FAO, WHO (2016) Manual on development and use of FAO and WHO specifications for pesticides, first edition-third revision. FAO plant production and protection paper, vol 228. World Health Organization; Food and Agriculture Organization of the United Nations, Rome

Farrar JJ, Baur ME, Elliott SF (2016) Measuring IPM impacts in California and Arizona. J Integr Pest Manag 7(1):13. https://doi. org/10.1093/jipm/pmw012

FDA (2019) Generally recognized as safe (GRAS). Food and Drug Administration of the United States of America. https://www.fda. gov/food/ingredientspackaginglabeling/gras/. Accessed 9 March 2019

Feng R, Isman MB (1995) Selection for resistance to azadirachtin in the green peach aphid, Myzus persicae. Experientia 51(8):831. https:// doi.org/10.1007/BF01922438

Fening KO, Amoabeng BW, Adama I, Mochiah MB, Braimah H, Owusu-Akyaw M, Narveh E, Ekyem SO (2013) Sustainable management of two key pests of cabbage, Brassica oleracea var. capitata L. (Brassicaceae), using homemade extracts from garlic and hot pepper. Org Agric 3(3-4):163. https://doi.org/10.1007/ s13165-014-0058-2

Fening KO, Adama I, Tegbe RE (2014) On-farm evaluation of homemade pepper extract in the management of pests of cabbage, Brassica oleraceae L., and french beans, Phaseolus vulgaris L., in two agro-ecological zones in Ghana. Afr Entomol 22(3):552. https:// doi.org/10.4001/003.022.0306

Figueiredo AC, Barroso JG, Pedro LG, Scheffer JJC (2008) Factors affecting secondary metabolite production in plants: volatile components and essential oils. Flavour Fragr J 23(4):213. https://doi.org/ 10.1002/ffj. 1875

Gahukar RT (2014) Factors affecting content and bioefficacy of neem (Azadirachta indica A. Juss.) phytochemicals used in agricultural pest control: a review. Crop Prot 62:93. https://doi.org/10.1016/j. cropro.2014.04.014

Ganjian I, Kubo I, Fludzinski P (1983) Insect antifeedant elemanolide lactones from Vernonia amygdalina. Phytochem 22(11):2525. https://doi.org/10.1016/0031-9422(83)80154-X

Gerken A, Suglo JV, Braun M, Egyir I, Fleisher G (2001) Pesticides use and policies in Ghana: an economic and institutional analysis of current practice and factors influencing pesticide use. Institute of Horticultural Economics, Hannover

Green PWC, Belmain SR, Ndakidemi PA, Farrell IW, Stevenson PC (2017) Insecticidal activity of Tithonia diversifolia and Vernonia amygdalina. Ind Crop Prod 110:15. https://doi.org/10.1016/j. indcrop.2017.08.021

Grzywacz D, Stevenson PC, Mushobozi WL, Belmain S, Wilson K (2014) The use of indigenous ecological resources for pest control in Africa. Food Sec 6(1):71. https://doi.org/10.1007/s12571-0130313-5

Gupta MP (2005) Efficacy of neem in combination with cow urine against mustard aphid and its effect on coccinellid predators. Nat Prod Radiance 4(2): 102

Gupta MP, Pathak RK (2009) Bioefficacy of neem products and insecticides against the incidence of whitefly, yellow mosaic virus and pod borer in black gram. Nat Prod Radiance 8(2):133 
Hafez M, Dimetry NZ, Abbass MH (2014) Efficacy of some plant products as protectants against Callosobruchus maculatus (F.) on mungbean seeds, Vigna radiata L. (Wilczek). Egypt J Biol Pest Control 24(2):353

Hassanein NM, Ali MM, Youssef KA, Mahmoud DA (2010) Control of tomato early blight and wilt using aqueous extract of neem leaves. Phytopathol Mediterr 49(2):143

Huang Y, Hee SK, Ho SH (1998) Antifeedant and growth inhibitory effects of $\alpha$-pinene on the stored-product insects, Tribolium castaneum (Herbst) and Sitophilus zeamais Motsch. Int Pest Control 40(1):18

Huang Y, Chen SX, Ho SH (2000) Bioactivities of methyl allyl disulfide and diallyl trisulfide from essential oil of garlic to two species of stored-product pests, Sitophilus zeamais (Coleoptera: Curculionidae) and Tribolium castaneum (Coleoptera: Tenebrionidae). J Econ Entomol 93(2):537. https://doi.org/10. 1603/0022-0493-93.2.537

Ibrahim A, Demisse G (2013) Evaluation of some botanicals against termites' damage on hot pepper at Bako, Western Ethiopia. Int J Agric Policy Res 1(2):48

Ileke KD, Oni MO (2011) Toxicity of some plant powders to maize weevil, Sitophilus zeamais (Motschulsky) [Coleoptera: Curculiondae] on stored wheat grains (Triticum aestivum). Afr J Agric Res 6(13):3043. https://doi.org/10.5897/AJAR11.622

Ilesanmi JO, Gungula DT (2010) Preservation of cowpea (Vigna unguiculata (L.) Walp) grains against cowpea bruchids (Callosobruchus maculatus) using neem and moringa seed oils. Int J Agron 2010(2):1. https://doi.org/10.1155/2010/235280

IOBC (2018) IOBC-WPRS pesticide side effect database. International Organisation for Biological and Integrared Control. http://www. iobc-wprs.org/restricted member/toolbox.cfm. Accessed 29 November 2018

Isman MB (2006) Botanical insecticides, deterrents, and repellents in modern agriculture and an increasingly regulated world. Annu Rev Entomol 51:45. https://doi.org/10.1146/annurev.ento.51.110104. 151146

Isman MB (2008) Botanical insecticides: for richer, for poorer. Pest Manag Sci 64(1):8. https://doi.org/10.1002/ps.1470

Isman MB (2017) Bridging the gap: moving botanical insecticides from the laboratory to the farm. Ind Crop Prod 110:10. https://doi.org/10. 1016/j.indcrop.2017.07.012

Isman MB, Grieneisen ML (2014) Botanical insecticide research: many publications, limited useful data. Trends Plant Sci 19(3):140. https:// doi.org/10.1016/j.tplants.2013.11.005

Isman MB, Koul O, Luczynski A, Kaminski J (1990) Insecticidal and antifeedant bioactivities of neem oils and their relationship to azadirachtin content. J Agric Food Chem 38(6):1406. https://doi. org/10.1021/jf00096a024

Jiménez-Martínez E, Mena-Garcia A, Rayo-Cruz I (2016) Productos botánicos para el manejo del ácaro blanco (Polyphagotarsonemus latus, Banks.) (Acarina; Tarsonemidae), en chiltoma (Capsicum annuum L.), en Masaya, Nicaragua. La Calera 15(24):13. https:// doi.org/10.5377/calera.v15i24.2933

Kamanula JF, Belmain SR, Hall DR, Farman DI, Goyder DJ, Mvumi BM, Masumbu FF, Stevenson PC (2017) Chemical variation and insecticidal activity of Lippia javanica (Burm. f.) Spreng essential oil against Sitophilus zeamais Motschulsky. Ind Crop Prod 110:75. https://doi.org/10.1016/j.indcrop.2017.06.036

Kamatenesi-Mugisha M, Deng AL, Ogendo JO, Omolo EO, Mihale JM, Otim M, Buyungo JP, Bett PK (2008) Indigenous knowledge of field insect pests and their management around Lake Victoria basin in Uganda. Afr J Environ Sci Technol 2(8):342

Kamatenesi-Mugisha M, Buyungo JP, Egwang P, Vudriko P, Gakunga JN, Deng A, Ogendo J, Mihale JM (2010) Evaluation of the biosafety of selected botanical pesticide plants used by subsistence farmers around the Lake Victoria basin. In: Ethnobotany and health:
Proceedings of the cluster workshop, Lake Victoria Research Institute, Uganda, pp 45-57

Kamel AM (2010) Can we use moringa oil as a botanical insecticide against Spodoptera frugiperda. Acad J Entomol 3(2):59

Kaniampady MM, Muhammed Arif M, Jirovetz L, Mohamed Shafi P (2007) Essential oil composition of Gliricidia sepium (Leguminosae) leaves and flowers. Indian J Chem 4B:1356

Kaputa F, Tembo L, Kurangwa W (2015) Efficacy of garlic (Allium sativum) and red chilli pepper (Capsicum annum) extracts in the control of red spider mite (Tetranychus urticae) in tomatoes (Lycopersicon esculentum). Asian J Appl Sci 3(1):124

Kar A, Ganguli J, Ganguli RN (2008) Testing of certain botanical leaf powders against oviposition of pulse beetle, Callosobruchus maculatus Fabr on chickpea. J Appl Zool Res 19(2):197

Kéita SM, Vincent C, Schmit J-P, Arnason JT, Bélanger A (2001) Efficacy of essential oil of Ocimum basilicum L. and $O$. gratissimum $\mathrm{L}$. applied as an insecticidal fumigant and powder to control Callosobruchus maculatus (Fab.) [Coleoptera : Bruchidae]. J Stored Prod Res 37(4):339. https://doi.org/10.1016/ S0022-474X(00)00034-5

Kemabonta KA, Falodu BB (2013) Bioefficacy of three plant products as post-harvest grain protectants against Sitophilus oryzae Linnaeus (Coleoptera: Curculionidae) on stored wheat (Triticum aestivum). Int J Sci Nat 4(2):259

Kesavachandran CN, Fareed M, Pathak MK, Bihari V, Mathur N, Srivastava AK (2009) Adverse health effects of pesticides in agrarian populations of developing countries. In: Reviews of environmental contamination and toxicology, vol 200. Springer, New York, pp 33-52

Kibrom G, Kebede K, Weldehaweria G, Dejen G, Mekonen S, Gebreegziabher E, Nagappan R (2012) Field evaluation of aqueous extract of Melia azedarach Linn. seeds against cabbage aphid, Brevicoryne brassicae Linn. (Homoptera: Aphididae), and its predator Coccinella septempunctata Linn (Coleoptera: Coccinellidae). Arch Phytopathol Plant Protect 45(11):1273. https://doi.org/10. 1080/03235408.2012.673260

Kim S-I, Yoon J-S, Jung JW, Hong K-B, Ahn Y-J, Kwon HW (2010) Toxicity and repellency of origanum essential oil and its components against Tribolium castaneum (Coleoptera : Tenebrionidae) adults. J Asia Pac Entomol 13(4):369. https://doi.org/10.1016/j.aspen.2010. 06.011

Kiruba S, Jeeva S, Kanagappan M, Stalin IS, Das SSM (2008) Ethnic storage strategies adopted by farmers of Tirunelveli district of Tamil Nadu, Southern Peninsular India. J Agric Technol 4(1):1

Klein W, Grabler W, Tischner H (2015) Sachkundig im Pflanzenschutz Arbeitshilfe zum Erlangen des Sachkundenachweises im Pflanzenschutz, 15th edn. Ulmer, Stuttgart (Hohenheim)

Kossou DK (1989) Evaluation des differents produits du neem Azadirachta indica A. Juss pour le controle de Sitophilus zeamais Motsch sur le mais en post-récolte. Int J Trop Insect Sci 10(03):365. https://doi.org/10.1017/S1742758400003623

Kossouoh C, Moudachirou M, Adjakidje V, Chalchat J-C, Figuérédo G, Chalard P (2011) Volatile constituents of Chromolaena odorata (L.) R.M. King \& H. Rob. Leaves from Benin. J Essent Oil Bear Plants 14(2):224. https://doi.org/10.1080/0972060X.2011.10643925

Kumar MM, Kumar S, Prasad CS, Kumar P (2015) Management of gram pod borer, Helicoverpa armigera (Hubner) in chickpea with botanical and chemical insecticide. J Exp Zool India 18(2):741

Lale NES, Abdulrahman HT (1999) Evaluation of neem (Azadirachta indica A. Juss) seed oil obtained by different methods and neem powder for the management of Callosobruchus maculatus (F.) (Coleoptera : Bruchidae) in stored cowpea. J Stored Prod Res 35(2):135. https://doi.org/10.1016/S0022-474X(98)00039-3

Lawal O, Opoku A, Ogunwande I (2015) Phytoconstituents and insecticidal activity of different solvent leaf extracts of Chromolaena odorata L., against Sitophilus zeamais (Coleoptera : 
Curculionidae). Eur J Med Plants 5(3):237. https://doi.org/10.9734/ EJMP/2015/6739

Law-Ogbomo KE, Enobakhare DA (2007) The use of leaf powders of Ocimum gratissimum and Vernonia amygdalina for the management of Sitophilus oryzae (Lin.) in stored rice. J Entomol 4(3):253. https://doi.org/10.3923/je.2007.253.257

Lee CY, Lo KC, Yao MC (2006) Effects of household soap solutions on the mortality of the two-spotted spider mite, Tetranychus urticae Koch (Acari: Tetranychidae). Formosan Entomol 26:379

Lingappa S, Basavanagoud K, Kulkarni KA, Patil RS, Kambrekar DN (2004) Threat to vegetable production by diamondback moth and its management strategies. In: Fruit and vegetable diseases. Kluwer Academic, Dordrecht, pp 357-396

Liu TX, Stansly PA (2000) Insecticidal activity of surfactants and oils against silverleaf whitefly (Bemisia argentifolii) nymphs (Homoptera : Aleyrodidae) on collards and tomato. Pest Manag Sci 56(10):861. https://doi.org/10.1002/1526-4998(200010)56: $10<861$ :AID-PS217>3.0.CO;2-Y

Longe OO (2016) Evaluating the efficacy of some plant powders on the bean weevil [Callosobruchus maculatus (fabricius) (Coleoptera: Bruchidae)] affecting stored cowpea seeds (Vigna unguiculata). Asian J Sci Technol 7(2):2486

Lynn OML (2010) Effects of Azadirachtin and neem-based formulations for the control of sweetpotato whitefly and root-knot nematode. J Korean Soc Appl Biol Chem 53(5):598. https://doi.org/10.3839/ jksabc. 2010.092

Maciorowski AF (1994) Azatin EC: Review of follow-up data for conditional registration. Acute contact toxicity to honeybee. United States Environmental Protection Agency. https://archive.epa.gov/ pesticides/chemicalsearch/chemical/foia/web/html/121701.html. Accessed 20 Mar 2019

Makaza K, Mabhegedhe M (2016) Smallholder farmers' indigenous knowledge of maize storage pests and pesticidal plant use: the case of wards 9 and 10 in Bikita District, Masvingo Province, Zimbabwe. Afr J Agric Res 11(47):4831

Mazzonetto F, Corbani RZ, Dalri AB (2013) Biofumigation of plant species on Sitophilus zeamais in stored maize. Appl Res Agrotec 6(1):53. https://doi.org/10.5935/PAeT.V6.N1.06

McKenna MM, Hammad EMA-F, Farran MT (2013) Effect of Melia azedarach (Sapindales : Meliaceae) fruit extracts on citrus leafminer Phyllocnistis citrella (Lepidoptera: Gracillariidae). Springerplus 2(1):144. https://doi.org/10.1186/2193-1801-2-144

Mkenda P, Mwanauta R, Stevenson PC, Ndakidemi P, Mtei K, Belmain SR (2015a) Extracts from field margin weeds provide economically viable and environmentally benign pest control compared to synthetic pesticides. PLoS One 10(11):e0143530. https://doi.org/10. 1371/journal.pone. 0143530

Mkenda PA, Stevenson PC, Ndakidemi P, Farman DI, Belmain SR (2015b) Contact and fumigant toxicity of five pesticidal plants against Callosobruchus maculatus (Coleoptera : Chrysomelidae) in stored cowpea (Vigna unguiculata). Int J Trop Insect Sci 35(04):172. https://doi.org/10.1017/S174275841500017X

Mkindi A, Mpumi N, Tembo Y, Stevenson PC, Ndakidemi PA, Mtei K, Machunda R, Belmain SR (2017) Invasive weeds with pesticidal properties as potential new crops. Ind Crop Prod 110:113. https:// doi.org/10.1016/j.indcrop.2017.06.002

Mlambo S, Mvumi BM, Stathers T, Mubayiwa M, Nyabako T (2017) Field efficacy of hermetic and other maize grain storage options under smallholder farmer management. Crop Prot 98:198

Mochiah MB, Banful B, Fening KO, Amoabeng B, Offei Bonsu K, Ekyem S, Braimah H, Owusu-Akyaw M (2011) Botanicals for the management of insect pests in organic vegetable production. $\mathrm{J}$ Entomol Nematol 6(3):85

Montes-Molina JA, Luna-Guido ML, Espinoza-Paz N, Govaerts B, Gutierrez-Miceli FA, Dendooven L (2008a) Are extracts of neem (Azadirachta indica A. Juss. (L.)) and Gliricidia sepium (Jacquin) an alternative to control pests on maize (Zea mays L.)? Crop Prot 27(3-5):763. https://doi.org/10.1016/j.cropro.2007.11.002

Montes-Molina JA, Luna-Guido M, Ceballos-Ramirez JM, FernándezLuqueño F, Espinoza-Paz N, Rincón-Rosales R, Dendooven L, Gutierrez-Miceli FA (2008b) Effect of pest-controlling neem and mata-raton on bean growth, soil $\mathrm{N}$ and soil $\mathrm{CO} 2$ emissions. Agron Sustain Dev 28(2):187. https://doi.org/10.1051/agro:2008002

Moreira MD, Picanço MC, Barbosa LCA, Guedes RNC, Barros EC, Campos MR (2007) Compounds from Ageratum conyzoides: isolation, structural elucidation and insecticidal activity. Pest Manag Sci 63(6):615. https://doi.org/10.1002/ps.1376

Morgan ED (2004) The place of neem among modern natural pesticides. In: Neem: today and in the new millennium. Kluwer Academic Publishers, Dordrecht, pp 21-32

Morgan ED (2009) Azadirachtin, a scientific gold mine. Bioorg Med Chem 17(12):4096. https://doi.org/10.1016/j.bmc.2008.11.081

Moronkola DO, Ogunwande IA, Walker TM, Setzer WN, Oyewole IO (2006) Identification of the main volatile compounds in the leaf and flower of Tithonia diversifolia (Hemsl) Gray. J Nat Med 61(1):63. https://doi.org/10.1007/s11418-006-0019-5

Musa A, Adewale S (2015) Peel and leaf powders of three fruits and a vegetable as promising botanicals against Callosobruchus maculatus F. J Agric Sci 60(4):455. https://doi.org/10.2298/ JAS1504455M

Naranjo SE, Ellsworth PC (2009) Fifty years of the integrated control concept: moving the model and implementation forward in Arizona. Pest Manag Sci 65(12):1267. https://doi.org/10.1002/ps. 1861

Narasimhamurthy GM, Ram K (2013) Field evaluation of some insecticides and bio-pesticide against tur pod bug, Clavigralla gibbosa (Spinola) in long duration pigeonpea. Afr J Agric Res 8(38):4876. https://doi.org/10.5897/AJAR2013.7238

Nathan SS, Kalaivani K, Murugan K (2005) Effects of neem limonoids on the malaria vector Anopheles stephensi Liston (Diptera: Culicidae). Acta Trop 96(1):47. https://doi.org/10.1016/j. actatropica.2005.07.002

Naumann K, Currie RW, Isman MB (1994) Evaluation of the repellent effects of a neem insecticide on foraging honey bees and other pollinators. Can Entomol 126(02):225. https://doi.org/10.4039/ Ent126225-2

Neuwinger HD (2004) Plants used for poison fishing in tropical Africa. Toxicon 44(4):417. https://doi.org/10.1016/j.toxicon.2004.05.014

Ngowi AVF, Mbise TJ, Ijani ASM, London L, Ajayi OC (2007) Pesticides use by smallholder farmers in vegetable production in Northern Tanzania. Crop Prot 26(11):1617. https://doi.org/10. 1016/j.cropro.2007.01.008

Nta AI, Ibiang YB, Uyoh EA, Edu NE, Ekanem BE, John QE (2013) Insect pest damage to leaves of cowpea (Vigna unguiculata L. Walp): comparative effects of aqueous extracts of Piper guineensis, Allium sativum and Myristica fragrans. J Environ Sci Toxicol Food Technol 3(2):17

Nyirenda SP, Sileshi GW, Belmain SR, Kamanula JF, Mvumi BM, Sola P, Nyirenda GKC, Stevenson PC (2011) Farmers' ethno-ecological knowledge of vegetable pests and pesticidal plant use in Northern Malawi and Eastern Zambia. Afr J Agric Res 6(2):41-49

Obembe OM, Kayode J (2013) Insecticidal activity of the aqueous extracts of four under-utilized tropical plants as protectant of cowpea seeds from Callosobruchus maculatus infestation. Pak J Biol Sci 16(4):175. https://doi.org/10.3923/pjbs.2013.175.179

Oerke EC (2006) Crop losses to pests. J Agric Sci 144(01):31. https://doi. org/10.1017/S0021859605005708

Ogbonnia S, Mbaka G, Anyika E, Osegbo O, Igbokwe N (2010) Evaluation of acute toxicity in mice and subchronic toxicity of hydro-ethanolic extract of Chromolaena odorata (L.) King and Robinson (Fam. Asteraceae) in rats. Agric Biol J N Am 1(5):859. https://doi.org/10.5251/abjna.2010.1.5.859.865 
Ogendo JO, Belmain SR, Deng AL, Walker DJ (2003) Comparison of toxic and repellent effects of Lantana camara L. with Tephrosia vogelii Hook and a synthetic pesticide against Sitophilus zeamais Motschulsky (Coleoptera: Curculionidae) in stored maize grain. Int J Trop Insect Sci 23(02):127. https://doi.org/10.1017/ S1742758400020348

Ogendo JO, Deng AL, Belmain SR, Walker DJ, Musandu AAO (2004) Effect of insecticidal plant materials, Lantana camara L. and Tephrosia vogelii Hook, on the quality parameters of stored maize grains. J Food Technol Afr 9(1):29

Ogendo JO, Kostyukovsky M, Ravid U, Matasyoh JC, Deng AL, Omolo EO, Kariuki ST, Shaaya E (2008) Bioactivity of Ocimum gratissimum L. oil and two of its constituents against five insect pests attacking stored food products. J Stored Prod Res 44:328

Ojo JA, Olunloyo AA, Akanni EO (2013) Efficacy of Moringa oleifera leaf powder against Callosobruchus maculatus (F.) (Coleoptera: Chrysomelidae) on stored cowpea (Vigna unguiculata L. Walp). Research 5(12):240

Ojo JA, Osunlola OS, Longe OO (2016) Comparative efficacy of three botanicals against Callosobruchus maculatus Fabricius (Coleoptera : Chrysomelidae: Bruchinae) in stored cowpea seeds. Egypt J Biol Pest Control 26(3):637

Okrikata E, Mai Bukar S, Ali B (2016) Economic viability of chilli pepper and neem seed kernel powdered formulations vis-à-vis Sevin dust (85\%) in the management of Lepidopterous stemborers on sorghum in North Eastern Nigeria. J Biol Agric Healthc 21(6):99

Olaitan AF, Abiodun AT (2011) Comparative toxicity of botanical and synthetic insecticides against major field insect pests of cowpea [Vigna unquiculata L. Walp]. J Nat Prod Plant Res 1(3):86

de Oliveira CFRL, Paiva LA, Coelho PMG, Barroso LCB, Marangoni S, Macedo MLR (2011) Evaluation of seed coagulant Moringa oleifera lectin $(\mathrm{cMoL})$ as a bioinsecticidal tool with potential for the control of insects. Process Biochem 46(2):498. https://doi.org/ 10.1016/j.procbio.2010.09.025

Onu I, Aliyu M (1995) Evaluation of powdered fruits of four peppers (Capsicum spp.) for the control of Callosobruchus maculatus (F) on stored cowpea seed. Int J Pest Manag 41(3):143. https://doi.org/10. 1080/09670879509371939

Onunkun O (2012) Evaluation of aqueous extracts of five plants in the control of flea beetles on okra (Abelmoschus esculentus L. Moench). J Biopestic 5:62

Oparaeke AM (2006) Field screening of nine plant extracts for the control of post-flowering insect pests of cowpea, Vigna unguiculata (L.) Walp. Arch Phytopathol Plant Protect 39(3):225. https://doi.org/10. 1080/03235400500094399

Oparaeke AM, Dike MC, Amatobi CI (2007) Effect of application of different concentrations and appropriate schedules of aqueous garlic (Allium sativum L.) bulb extracts against Maruca vitrata and Clavigralla tomentosicollis on cowpea, Vigna unguiculata L. Walp. Arch Phytopathol Plant Protect 40(4):246. https://doi.org/10. 1080/03235400500383941

Osipitan AA, Lasisi AM, Mumuni HM, Ewedairo BI (2014) Evaluation of some plant products for the management of Prostephanus truncatus (Horn) (Coleoptera : Bostrichidae) in stored maize (Zea mays ) and their effect on nutritional composition of the kernels. Arch Phytopathol Plant Protect 47(9):1072. https://doi.org/10. 1080/03235408.2013.829983

Ouedraogo I, Sawadogo A, Nebie RC, Dakouo D (2016) Evaluation of the toxicity of essential oils of Cymbopogon nardus (L) and Ocimum gratissimum (L) against maize insects Sitophilius zeamais Motsch and Rhyzopertha dominica $\mathrm{F}$, the major insect pests in maize storage in Burkina Faso. Int J Biol Chem Sci 10(2):695

Owolabi MS, Ogundajo A, Yusuf KO, Lajide L, Villanueva HE, Tuten JA, Setzer WN (2010) Chemical composition and bioactivity of the essential oil of Chromolaena odorata from Nigeria. Records Nat Prod 4(1):72
Owolade OF, Alabi BS, Osikanlu YOK, Odeyemi OO (2004) On-farm evaluation of some plant extracts as biofungicide and bioinsecticide on cowpea in Southwest Nigeria. J Food Agric Environ 2(2):237

Pamela Nuñez O, Gonzalo Silva A, Maritza Tapia V, Ruperto Hepp G, Rodríguez-Maciel JC, Lagunes-Tejeda A (2010) Toxicity of leaf powders of Mexican tea (Chenopodium ambrosioides L.) and boldo (Peumus boldus Mol.) singly and mixed with calcium carbonate against maize weevil (Sitophilus zeamais Motschulsky). AgroCiencia 26(2):71

Parvathi K, Jamil K (1999) Toxic, growth-inhibitory and antifeedant activity of Gliricidia sepium Jacq. leaf extract against Dysdercus koenigii Fabricius, Achaea janata Linnaeus and Spodoptera litura Fabricius. Int J Trop Insect Sci 19(2-3):217. https://doi.org/10.1017/ S1742758400019500

Passoni FD, Oliveira RB, Chagas-Paula DA, Gobbo-Neto L, Da Costa FB (2013) Repeated-dose toxicological studies of Tithonia diversifolia (Hemsl.) A. Gray and identification of the toxic compounds. J Ethnopharmacol 147(2):389. https://doi.org/10.1016/j. jep.2013.03.024

Patil RS, Nandihalli BS (2009) Efficacy of promising botanicals against red spider mite on brinjal. Karnataka J Agric Sci 22(3):690

Paul UV, Lossini JS, Edwards PJ, Hilbeck A (2009) Effectiveness of products from four locally grown plants for the management of Acanthoscelides obtectus (Say) and Zabrotes subfasciatus (Boheman) (both Coleoptera : Bruchidae) in stored beans under laboratory and farm conditions in Northern Tanzania. J Stored Prod Res 45(2):97. https://doi.org/10.1016/j.jspr.2008.09.006

Pereira J, Wohlgemuth R (1982) Neem (Azadirachta indica A. Juss) of West African origin as a protectant of stored maize. J Appl Entomol 94(1-5):208. https://doi.org/10.1111/j.1439-0418.1982.tb02567.x

Pimentel D, Acquay H, Biltonen M, Rice P, Silva M, Nelson J, Lipner V, Giordano S, Horowitz A, D'Amore M (1992) Environmental and economic costs of pesticide use. BioScience 42(10):750. https://doi. org/10.2307/1311994

Prakash G, Emmannuel CJSK, Srivastava AK (2005) Variability of azadirachtin in Azadirachta indica (neem) and batch kinetics studies of cell suspension culture. Biotechnol Bioprocess Eng 10(3):198. https://doi.org/10.1007/BF02932013

Prowse GM, Galloway TS, Foggo A (2006) Insecticidal activity of garlic juice in two dipteran pests. Agric Forest Ent 8(1):1. https://doi.org/ 10.1111/j.1461-9555.2006.00273.x

Pubchem (2018) Rotenone: safety and hazards. National Center for Biotechnology Information. https://pubchem.ncbi.nlm.nih.gov/ compound/rotenone\#section=Safety-and-Hazards. Accessed 11 January 2018

Rajappan K, Ushamalini C, Subramanian N, Narasimhan V, Abdul Kareem A (2000) Effect of botanicals on the population dynamics of Nephotettix virescens, rice tungro disease incidence and yield of rice. Phytoparasitica 28(2):109. https://doi.org/10.1007/ BF02981739

Rendón-Huerta JA, Juarez-Flores BI, Aguirre-Rivera JR, Fuentes GA (2013) Insecticide effect of wild plant powders on bean weevil (Zabrotes subfasciatus Boheman; Coleoptera : Bruchidae) in vitro. Afr J Agric Res 8(11):971. https://doi.org/10.5897/AJAR12.1757

Roobakkumar A, Subramaniam MSR, Babu A, Muraleedharan N (2010) Bioefficacy of certain plant extracts against the red spider mite, Oligonychus coffeae (Nietner) (Acarina : Tetranychidae) infesting tea in Tamil Nadu, India. Int J Acarol 36(3):255. https://doi.org/10. 1080/01647951003652592

Roy S, Handique G, Muraleedharan N, Dashora K, Roy SM, Mukhopadhyay A, Babu A (2016) Use of plant extracts for tea pest management in India. Appl Microbiol Biotechnol 100(11):4831. https://doi.org/10.1007/s00253-016-7522-8

Sahid IB, Sugau JB (1993) Allelopathic effect of lantana (Lantana camara) and Siam weed (Chromolaena odorata) on selected crops. Weed Sci 41(2):303 
Said F, Inayatullah M, Ahmad S, Khan IA, Saeed-ul-Haq ZM (2015) Comparing the effect of different plant extracts with a chemical insecticide for management of the aphid, Aphis gossypii in sunflower. Pak J Weed Sci Res 21(3):359

Sarasan V, Kite GC, Sileshi GW, Stevenson PC (2011) Applications of phytochemical and in vitro techniques for reducing over-harvesting of medicinal and pesticidal plants and generating income for the rural poor. Plant Cell Rep 30:1163. https://doi.org/10.1007/ s00299-011-1047-5

Saxena RC (1998) Botanical pest control. In: Critical reviews in insect pest management. Commonwealth Publishers, New Dehli, pp 155179

Sharma N, Qadry JS, Subramanium B, Verghese T, Rahman SJ, Sharma SK, Jalees S (1998) Larvicidal activity of Gliricidia sepium against mosquito larvae of Anopheles stephansi, Aedes aegypti and Culex quinquefasciatus. Pharm Biol 36(1):3. https://doi.org/10.1076/phbi. 36.1.3.4616

Shiberu T, Negeri M, Thangavel S (2012) Evaluation of some botanicals and entomopathogenic fungi for the control of onion thrips (Thrips tabaci L.) in West Showa, Ethiopia. J Plant Pathol Microb 04:01. https://doi.org/10.4172/2157-7471.1000161

Sidhu OP, Kumar V, Behl HM (2003) Variability in neem (Azadirachta indica) with respect to azadirachtin content. J Agric Food Chem 51(4):910. https://doi.org/10.1021/jf025994m

Singh D, Singh AK (1991) Repellent and insecticidal properties of essential oils against housefly, Musca domestica L. Int J Trop Insect Sci 12(04):487. https://doi.org/10.1017/S1742758400011401

Singh KI, Singh TR, Thokchom J, Devi SS (2013) Biology and botanical based management of Pieris brassicae Linn. on cabbage cropecosystem of Manipur Valley. J Appl Zool Res 24(2):113

Sivira A, Sanabria ME, Valera C, Vásquez C (2011) Toxicity of ethanolic extracts from Lippia origanoides and Gliricidia sepium to Tetranychus cinnabarinus (Boisduval) (Acari: Tetranychidae). Neotrop Entomol 40(3):375. https://doi.org/10.1590/S1519. 566X2011000300011

Smith TM, Stratton GW (1986) Effects of synthetic pyrethroid insecticides on nontarget organisms. In: Residue reviews. Springer, New York, pp 93-120

Soares WL, Porto MFDS (2012) Pesticide use and economic impacts on health. Rev Saude Publica 46(2):209

Stevenson PC, Kite GC, Lewis GP, Forest F, Nyirenda SP, Belmain SR, Sileshi GW, Veitch NC (2012) Distinct chemotypes of Tephrosia vogelii and implications for their use in pest control and soil enrichment. Phytochem 78:135. https://doi.org/10.1016/j.phytochem. 2012.02.025

Stevenson PC, Isman MB, Belmain SR (2017) Pesticidal plants in Africa: a global vision of new biological control products from local uses. Ind Crop Prod 110:2. https://doi.org/10.1016/j.indcrop.2017.08.034

Tanner CM, Kamel F, Ross GW, Hoppin JA, Goldman SM, Korell M, Marras C, Bhudhikanok GS, Kasten M, Chade AR, Comyns K, Richards MB, Meng C, Priestley B, Fernandez HH, Cambi F, Umbach DM, Blair A, Sandler DP, Langston JW (2011) Rotenone, paraquat, and Parkinson's disease. Environ Health Perspect 119(6):866. https://doi.org/10.1289/ehp.1002839

Tapondjou LA, Adler C, Bouda H, Ajong Fontem D (2003) Bioefficacité des poudres et des huiles essentielles des feuilles de Chenopodium ambrosioides et Eucalyptus saligna à l'égard de la bruche du niébé, Callosobruchus maculatus Fab. (Coleoptera: Bruchidae). Cah Agric 12:401
Tembo Y, Mkindi AG, Mkenda PA, Mpumi N, Mwanauta R, Stevenson PC, Ndakidemi PA, Belmain SR (2018) Pesticidal plant extracts improve yield and reduce insect pests on legume crops without harming beneficial arthropods. Front Plant Sci 9:1425. https://doi. org/10.3389/fpls.2018.01425

Vasileiadis VP, Dachbrodt-Saaydeh S, Kudsk P, Colnenne-David C, Leprince F, Holb IJ, Kierzek R, Furlan L, Loddo D, Melander B, Jørgensen LN, Newton AC, Toque C, van Dijk W, Lefebvre M, Benezit M, Sattin M (2017) Sustainability of European winter wheat- and maize-based cropping systems: economic, environmental and social ex-post assessment of conventional and IPM-based systems. Crop Prot 97:60. https://doi.org/10.1016/j.cropro.2016.11. 002

Vera N, Popich S, Luna L, Cravero R, González Sierra M, Bardón A (2006) Toxicity and synergism in the feeding deterrence of some coumarins on Spodoptera frugiperda Smith (Lepidoptera : Noctuidae). Chem Biodivers 3(1):21. https://doi.org/10.1002/cbdv. 200690002

Weinberger K, Srinivasan R (2009) Farmers' management of cabbage and cauliflower pests in India and their approaches to crop protection. J of Asia-Pac Entomol 12(4):253. https://doi.org/10.1016/j. aspen.2009.08.003

WHO (2009) The WHO recommended classification of pesticides by hazard. World Health Organization, Rome

Witt JM (2012) PSEP fact sheets: adjuvants. Cornell University Cooperative Extension. http://psep.cce.cornell.edu/facts-slides-self/ facts/gen-peapp-adjuvants.aspx. Accessed 25 January 2017

Xavier VM, Picanço MC, Bacci L, Silva GA, Benevenute JS et al (2010) Impact of botanical insecticides on indigenous stingless bees (Hymenoptera : Apidae). Sociobiol 56(3):713

Xavier VM, Message D, Picanço MC, Chediak M, Júnior PAS, Ramos RS, Martins JC (2015) Acute toxicity and sublethal effects of botanical insecticides to honey bees. J Insect Sci 15(1):137. https://doi. org/10.1093/jisesa/iev110

Yakkundi SR, Thejavathi R, Ravindranath B (1995) Variation of azadirachtin content during growth and storage of neem (Azadirachta indica) seeds. J Agric Food Chem 43(9):2517. https://doi.org/10.1021/jf00057a036

Yang FL, Zhu F, Lei CL (2012) Insecticidal activities of garlic substances against adults of grain moth, Sitotroga cerealella (Lepidoptera : Gelechiidae). Insect Sci 19(2):205. https://doi.org/10.1111/j.17447917.2011.01446.x

Yusuf AU, Dike MC, Adebitan SA, Ahmed BI (2011) Comparative efficacy of seven plant products on the cowpea bruchid, Callosobruchus maculatus F. development and damage. J Biopestic 4(1): 19

Zhao NN, Zhang H, Zhang XC, Luan XB, Zhou C, Liu QZ, Shi WP, Liu ZL (2013) Evaluation of acute toxicity of essential oil of garlic (Allium sativum) and its selected major constituent compounds against overwintering Cacopsylla chinensis (Hemiptera : Psyllidae). J Econ Entomol 106(3):1349. https://doi.org/10.1603/ EC12191

Publisher's note Springer Nature remains neutral with regard to jurisdictional claims in published maps and institutional affiliations. 